\title{
Resolving community metabolism of eelgrass Zostera marina meadows by benthic flume-chambers and eddy covariance in dynamic coastal environments
}

\author{
Nicola Camillini ${ }^{1,2, *}$, Karl M. Attard ${ }^{2,3}$, Bradley D. Eyre $^{1}$, Ronnie N. Glud ${ }^{2,4}$ \\ ${ }^{1}$ Centre for Coastal Biogeochemistry, Faculty of Science and Engineering, Southern Cross University, \\ 2480 Lismore, New South Wales, Australia \\ ${ }^{2}$ Department of Biology, Hadal \& Nordcee, University of Southern Denmark, 5230 Odense M, Denmark \\ ${ }^{3}$ Tvärminne Zoological Station, University of Helsinki, J.A. Palménin tie 260, 10900 Hanko, Finland \\ ${ }^{4}$ Department of Ocean and Environmental Sciences, Tokyo University of Marine Science and Technology, \\ 26 108-8477 Tokyo, Japan
}

\begin{abstract}
Sediment resuspension is a common process in dynamic coastal settings, but its implications for remineralization and carbon turnover in seagrass meadows are poorly understood. Here, we assessed eelgrass Zostera marina metabolism in the Baltic Sea (SW Finland) using benthic flume-chambers and aquatic eddy covariance to critically evaluate the drivers of benthic $\mathrm{O}_{2}$ exchange during dynamic flow conditions. During quiescent weather conditions, the 2 methods resolved similar metabolic rates and net ecosystem autotrophy $( \pm 11 \%$ of each other). However, elevated flow speeds and sediment resuspension halfway through the study induced a 5 -fold increase in the $\mathrm{O}_{2}$ uptake rates measured by eddy covariance, whereas chamber fluxes remained relatively unchanged. Following particle resettlement, instruments were redeployed and the benthic $\mathrm{O}_{2}$ uptake resolved by both techniques was just $\sim 30 \%$ of the values measured before resuspension. Laboratory investigations revealed sediment resuspension could potentially increase benthic $\mathrm{O}_{2}$ uptake up to 6-fold, mainly due to the reoxidation of reduced compounds (e.g. $\mathrm{FeS}_{\mathrm{x}}$ ). This process was fully captured by the eddy $\mathrm{O}_{2}$ fluxes, but not by the chamber incubation. Consequently, the chamber and eddy net ecosystem metabolism amounted to -17 and $-824 \mathrm{mmol} \mathrm{C} \mathrm{m}^{-2}$, respectively, throughout the study period. The rapid reoxidation and long-term effects of resuspension on benthic $\mathrm{O}_{2}$ dynamics highlight the importance of fully capturing dynamic conditions when assessing the overall carbon turnover in coastal habitats. Future studies on the biogeochemical functioning of coastal environments should aim to capture the natural frequency and duration of resuspension events.
\end{abstract}

KEY WORDS: Benthic oxygen exchange $\cdot$ Seagrass $\cdot$ Oxygen storage $\cdot$ Wind waves $\cdot$ Sediment resuspension

\section{INTRODUCTION}

Seagrasses are aquatic flowering plants that form extensive and diversity-rich coastal habitats (Duarte et al. 2008), wherein dampened hydrodynamics facilitate the entrapment of allochthonous material (Hendriks et al. 2008). Seagrass meadows have high productivity, which further contributes to carbon se-

*Corresponding author: ncamillini@bio.au.dk questration at amounts considered of global importance (Duarte et al. 2005, Fourqurean et al. 2012), an aspect that has recently received increasing attention (Mazarrasa et al. 2018, Macreadie et al. 2019). Shallow coastal settings and seagrass meadows are typically exposed to dynamic flow and wave action that can induce sediment resuspension (Koch 1999, Gacia \& Duarte 2001, Dahl et al. 2018). Resuspension

(C) The authors 2021. Open Access under Creative Commons by Attribution Licence. Use, distribution and reproduction are unrestricted. Authors and original publication must be credited. 
events change the local light availability, facilitate oxidation of reduced constituents released from the sediment, stimulate benthic mineralization, and might relocate deposited organic material and consolidated sediment (Ståhlberg et al. 2006, Almroth et al. 2009, Dahl et al. 2018, Forsberg et al. 2018). It is thus crucial to capture the natural effects of sediment resuspension to assess mineralization and retention of organic material in seagrass habitats. However, due to logistic and technical challenges, assessments on the biogeochemical functioning of seagrass meadows have overlooked this important aspect.

Sediment-water oxygen $\left(\mathrm{O}_{2}\right)$ exchange rate (or benthic $\mathrm{O}_{2}$ flux) is the most widely used proxy for assessing benthic carbon turnover and metabolic rates (Canfield 1993, Glud 2008), such as respiration ( $R$, negative flux), net daytime production (NDP), and gross primary production $(\mathrm{GPP}=\mathrm{NDP}+|\mathrm{R}|)$. The approach assumes a night-time respiratory quotient $\left(R Q ; \Sigma C O_{2}\right.$ produced $: O_{2}$ consumed ratio, where $\Sigma \mathrm{CO}_{2}$ is total dissolved inorganic carbon) approaching unity and a corresponding daytime photosynthetic quotient (Fenchel \& Glud 2000). The rationale for using $\mathrm{O}_{2}$ uptake rate as a measure for total benthic respiration (or carbon mineralization) is that most reduced equivalents, such as ferrous iron (Fe[II]) and sulphide $\left(\mathrm{H}_{2} \mathrm{~S}\right)$, produced through anaerobic mineralization, are ultimately reoxidized by $\mathrm{O}_{2}$. However, reduced equivalents transiently accumulate in many coastal sediments (i.e. $R Q>1$ ), as re-oxidation processes are shifted to periods with reduced mineralization intensity and/or enhanced benthic $\mathrm{O}_{2}$ availability (i.e. RQ < 1) (Therkildsen \& Lomstein 1993). Thus, the benthic $\mathrm{O}_{2}$ consumption rates measured at any one point throughout the year do not necessarily reflect concurrent mineralization rates, but rather integrate the microbial activity for longer and undefined periods (Glud 2008). As such, it is crucial to capture natural variation in benthic $\mathrm{O}_{2}$ fluxes over appropriate timescales to accurately assess benthic carbon turnover of coastal ecosystems. Particularly, benthic $\mathrm{O}_{2}$ fluxes tend to exhibit a relatively high day-to-day variability in ecosystems exposed to dynamic flow conditions (Berg et al. 2013, Rheuban et al. 2014, Attard et al. 2015, Gruber et al. 2017), while seasonal variability is more common in sheltered settings (Glud et al. 2003, Chipman et al. 2016).

In situ benthic $\mathrm{O}_{2}$ exchange rates are traditionally estimated by benthic chamber incubations, where the $\mathrm{O}_{2}$ exchange rate is calculated from changes in dissolved $\mathrm{O}_{2}$ concentration over time within a small (typically $<0.2 \mathrm{~m}^{2}$ ) and physically isolated sediment area. To avoid large build up or depletion of $\mathrm{O}_{2}$, incu- bations typically only last a few hours, depending on the enclosed biomass and the volume to surface area ratio of the applied chamber (Olivé et al. 2016). Daily rates are subsequently extrapolated from discrete flux measurements by accounting for the variable in situ irradiance (e.g. Martin et al. 2005). By excluding the natural flow conditions, the enclosed water is generally centrally and gently stirred (e.g. rotating discs or magnetic bars), thereby imposing artificial flow dynamics which are markedly different from natural flow patterns. This influences the resolved solute exchange rates, particularly in permeable sediments (Booij et al. 1991, Huettel \& Gust 1992, Glud et al. 1996). Compared to conventional rotating stirrers, pump diffuser designs induce internal water flow above the enclosed sediment surface that is likely to better mimic natural flow conditions (Webb \& Eyre 2004b). Flume-chambers with horizontal flow and high volume to surface area ratio enable diel flux measurements even in highly productive seagrass habitats (Maher \& Eyre 2010, 2011, Eyre et al. 2013). This chamber design, combined with $\mathrm{O}_{2}$ sensor measurements, can therefore provide continuous flux measurements at a high temporal resolution for relatively long incubation times.

Contrary to chamber incubations, open-water approaches quantify in situ fluxes under natural flow conditions. The aquatic eddy covariance technique is a non-invasive method for measuring in situ benthic $\mathrm{O}_{2}$ exchange rates at a high temporal resolution $(\leq 1 \mathrm{~h})$ over consecutive days (Berg et al. 2003). Dataprocessing protocols for this relatively recent technique are still evolving (e.g. Berg et al. 2019), but procedures typically resolve $15 \mathrm{~min}$ fluxes from rapid measurements of vertical flow velocity and $\mathrm{O}_{2}$ concentration, providing insight into the benthic $\mathrm{O}_{2}$ dynamics with high temporal resolution. Additionally, this method integrates the benthic activity of a 10-100 $\mathrm{m}^{2}$ large seafloor area located upstream of the instrument (Berg et al. 2007). The $\mathrm{O}_{2}$ exchange rates thus integrate patchy and complex benthic communities and are resolved under natural light and flow dynamics (Berg et al. 2013, Rheuban \& Berg 2013, Attard et al. 2014). Eddy covariance fully captures the $\mathrm{O}_{2}$ flux dynamics associated with natural in situ conditions such as tidally driven flow, waves, storm surges, and sediment resuspension (Berg \& Huettel 2008, McGinnis et al. 2014, Rheuban et al. 2014, Reimers et al. 2016). Sudden increases in flow velocity are often followed by changes in ambient water turbidity and light availability. While it can be challenging to disentangle the main drivers of seafloor metabolism based on the habitat-scale eddy 
covariance technique, enclosure approaches such as chamber incubations can resolve changes in biogeochemical processes and $\mathrm{O}_{2}$ utilization pathways during artificially induced sediment resuspension (Niemistö et al. 2018, Niemistö \& Lund-Hansen 2019). Therefore, combining these 2 different methods offers the potential to resolve true in situ seafloor metabolism, while disentangling the effects of dynamic environmental drivers (e.g. light availability and flow velocity). Despite the importance of seagrass meadows for the biological and geochemical function of most coastal oceans, to our knowledge there are no direct assessments of the effects of resuspension on benthic metabolism.

In this study, we aimed to resolve the effects of sediment resuspension on benthic $\mathrm{O}_{2}$ exchange in a temperate eelgrass Zostera marina meadow. In order to critically evaluate the drivers of the $\mathrm{O}_{2}$ exchange rates, we performed measurements using 2 state-ofthe-art in situ methods: benthic flume-chambers and aquatic eddy covariance. Both techniques were deployed side-by-side during typical hydrodynamic conditions for coastal settings, which included quiescent and wind-driven resuspension periods. In parallel with these measurements, we performed laboratory experiments to investigate potential changes and drivers of RQ during the in situ deployments. The comparison enabled us to assess the importance of resuspension for resolving the net metabolism and thus the carbon sequestration capacity of seagrass ecosystems using $\mathrm{O}_{2}$ measurements.

\section{MATERIALS AND METHODS}

\subsection{Study site and instrument deployment}

Fieldwork was carried out in August 2018 at Henriksberg Bay located near the Hanko Peninsula in the Gulf of Finland $\left(59^{\circ} 49.663^{\prime}\right.$ N, $\left.23^{\circ} 9.267^{\prime} \mathrm{E}\right)$, approximately $5 \mathrm{~km}$ SW of the Tvärminne Zoological Station (Fig. 1a). At this location, the common eelgrass Zostera marina forms large meadows at water depths between $\sim 1.5$ and $4.5 \mathrm{~m}$. The meadow mosaics are
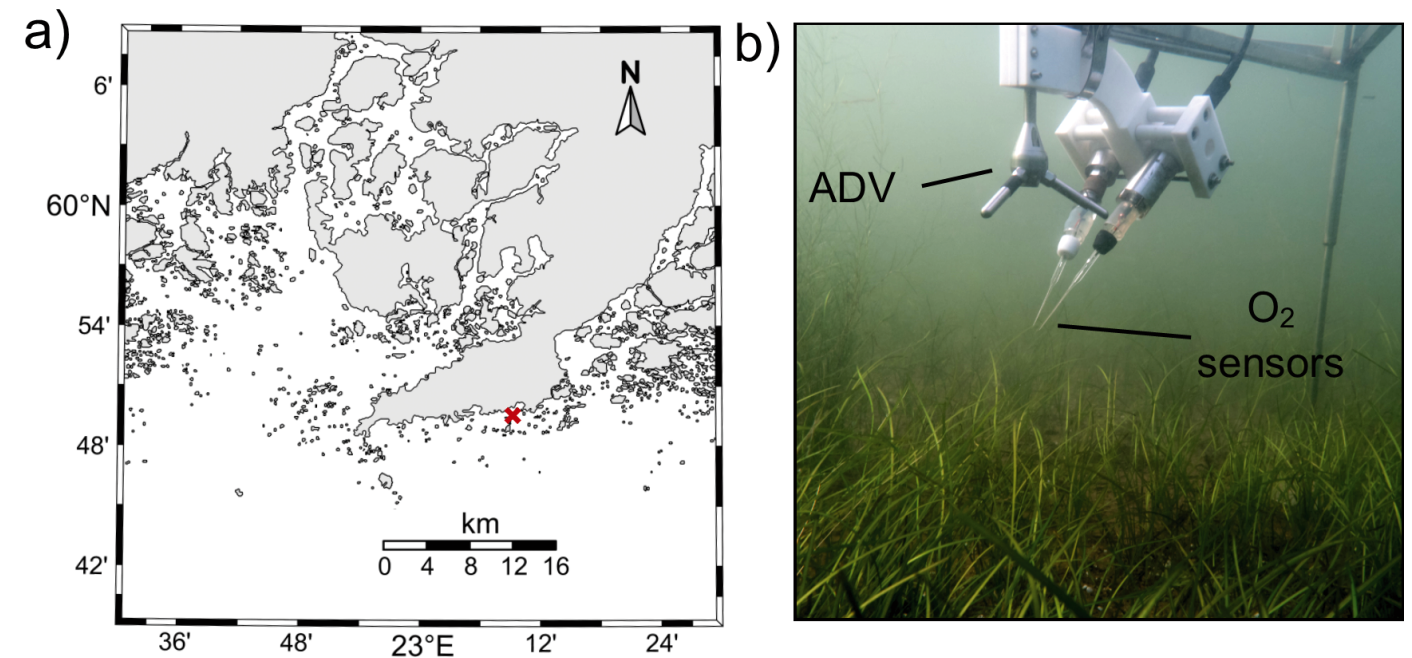

c)

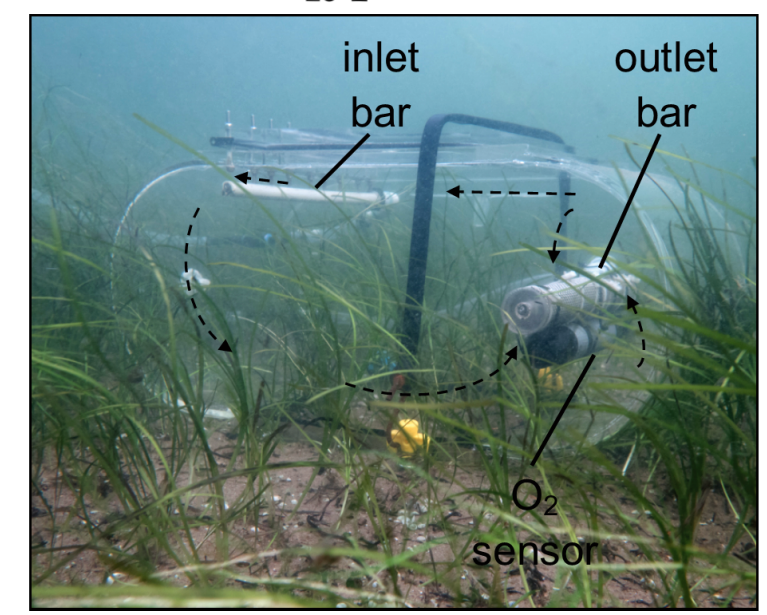

Fig. 1. (a) Location of the studied eelgrass meadow in SW Finland (red cross). (b) Close-up of the $\mathrm{O}_{2}$ sensors and acoustic Doppler velocimeter (ADV) mounted on the eddy instrument with sampling volume at $35 \mathrm{~cm}$ above the seafloor. (c) One of the 3 replicate chambers deployed at $\sim 5 \mathrm{~m}$ distance from the eddy instrument. The dashed arrows show the internal water flow-path originating from the inlet diffuser bar 
interspersed with sandy silt and functionally impermeable sediment, as inferred from laboratory microprofiles measured in intact sediment cores under different flow conditions (data not shown). Despite a small tidal range $( \pm 0.01 \mathrm{~m})$, the embayment is largely exposed within the south-west direction and often experiences along-shore currents and surface waves. The study was conducted within a large ( 20 m diameter) continuous seagrass meadow at a depth of $3.5 \mathrm{~m}$ that was composed primarily of $Z$. marina, although other macrophytes, most notably Myriophyllum sp., Potamogeton perfoliatus, Stuckenia pectinata, and Zannichellia sp., were also present. Benthic $\mathrm{O}_{2}$ fluxes in the seagrass meadow were quantified in situ by aquatic eddy covariance (hereafter eddy, Fig. 1b) and benthic flume-chambers (hereafter chambers, Fig. 1c). The chambers and eddy instruments were deployed by SCUBA divers, side-by-side, on 2 occasions in August 2018; the first deployment was from 7 to 12 August, and the second deployment was from 13 to 16 August. During each deployment, 3 chambers were used for spatial replication and were placed $<2 \mathrm{~m}$ from each other, while the eddy instrument was positioned at the centre of the meadow, $\sim 5 \mathrm{~m}$ upstream from the chambers. During the time between the 2 deployments, all instruments were checked and cleaned, and the batteries were recharged.

\subsection{Benthic chamber incubations}

The transparent acrylic chambers enclosed a sediment area of $0.084 \mathrm{~m}^{2}$ to a sediment depth of $10 \mathrm{~cm}$ and had a rectangular geometry $(\mathrm{L} \times \mathrm{W} \times \mathrm{H} ; 70 \mathrm{~cm} \times$ $30 \mathrm{~cm} \times 30 \mathrm{~cm})($ Eyre et al. 2011a). An important feature of these chambers was the high volume to surface area ratio (52 1:0.084 $\left.\mathrm{m}^{2}\right)$, which minimised artefacts typically associated with enclosure techniques in systems with high flux rates, and allowed extended incubation times (Webb \& Eyre 2004a,c, Maher \& Eyre 2011). Additionally, the short sides of the chambers were rounded to allow stirred water to flow laterally across the enclosed central square of sediment. The water was stirred using a closed pump circuit (Rule IL280P) attached to inlet and outlet diffuser bars positioned within the rounded sides of the chambers (Fig. 1c). The pumps were powered by $12 \mathrm{~V}$ submersible batteries (Deep Sea Power \& Light) through a power control (M171 Kemo Electronic) interfaced with a potentiometer (3296 Bourns) to obtain a constant flow of $4.3 \mathrm{l} \mathrm{min}^{-1}$ across the sediment surface for up to $\sim 110$ h. Based on theoretical calculations and laboratory tests, this corresponded to a maximum flow velocity between 2.5 and $3.5 \mathrm{~cm} \mathrm{~s}^{-1}$ across the sediment surface. The diffuser bars consisted of acrylic tubes (internal diameter [I.D.] $<1.5 \mathrm{~cm}$ ) positioned parallel to the sediment surface, with inlet and outlet bars each positioned at 28 and $15 \mathrm{~cm}$ from the sediment surface. To optimize the horizontal water flow across the sediment surface, the inlet bar had $1 \mathrm{~mm}$ diameter holes every $5 \mathrm{~mm}$ facing the rounded wall. The outlet bar had $5 \mathrm{~mm}$ diameter holes every 10$15 \mathrm{~mm}$ and was covered by a $1 \mathrm{~mm}$ mesh filter (outer diameter: $4.5 \mathrm{~cm}$ ) to avoid clogging and to avoid damaging seagrass during the incubation.

For deployment, chambers were carefully pushed into the sediment by divers and kept open for $0.5-1 \mathrm{~h}$ (pre-incubation time) with the pumps activated, allowing free exchange of water. Incubation commenced when the chambers were sealed. The $\mathrm{O}_{2}$ concentration and temperature in each chamber were recorded with an $\mathrm{O}_{2}$ optode (Dissolved Oxygen Logger U26-001, HOBO) that was mounted onto the outlet bar. The cross-calibrated optodes were programmed to record dissolved $\mathrm{O}_{2}$ concentration (accuracy $\pm 6.25 \mu \mathrm{mol} \mathrm{l}{ }^{-1}$, precision $0.63 \mu \mathrm{mol} \mathrm{l} \mathrm{l}^{-1}, 90 \%$ response time $\left[\mathrm{T}_{90}\right]$ $<2 \mathrm{~min}$ ) and temperature (accuracy $\pm 0.2^{\circ} \mathrm{C}$ ) at $1 \mathrm{~min}$ intervals. Benthic $\mathrm{O}_{2}$ fluxes were calculated for $15 \mathrm{~min}$ time periods by performing linear regression on 15 consecutive measurement points of $\mathrm{O}_{2}$ concentration over time, accounting for the enclosed water volume and sediment surface (Fig. 2a). Subsequently, the $15 \mathrm{~min}$ fluxes were binned into $1 \mathrm{~h}$ intervals to compare chambers and eddy fluxes (see Section 2.3) on identical timescales. Approximately halfway through deployment No. 1, the batteries powering the internal water stirring were recovered and recharged for $5 \mathrm{~h}$, while chambers were opened, and the internal volume was flushed to re-establish the internal $\mathrm{O}_{2}$ levels in the enclosed chamber water. The missing fluxes from this $5 \mathrm{~h}$ period were gap-filled using the photosynthesis-irradiance (P-I) relationship (see Section 2.5). This overall corresponded to 2 chamber deployments and 3 individual incubations lasting between 48 and $62 \mathrm{~h}$.

\subsection{Eddy covariance measurements}

The eddy instrument consisted of a $6 \mathrm{MHz}$ acoustic Doppler velocimeter (ADV; Nortek) that was interfaced with 2 independent $\mathrm{O}_{2}$ microsensors connected to submersible amplifiers (McGinnis et al. 2011). We used fast-response $\left(\mathrm{T}_{90} \leq 0.3 \mathrm{~s}\right)$ Clark-type $\mathrm{O}_{2}$ microelectrodes with low stirring sensitivity of $<1 \%$ (Revsbech 1989, Gundersen et al. 1998). The equipment 


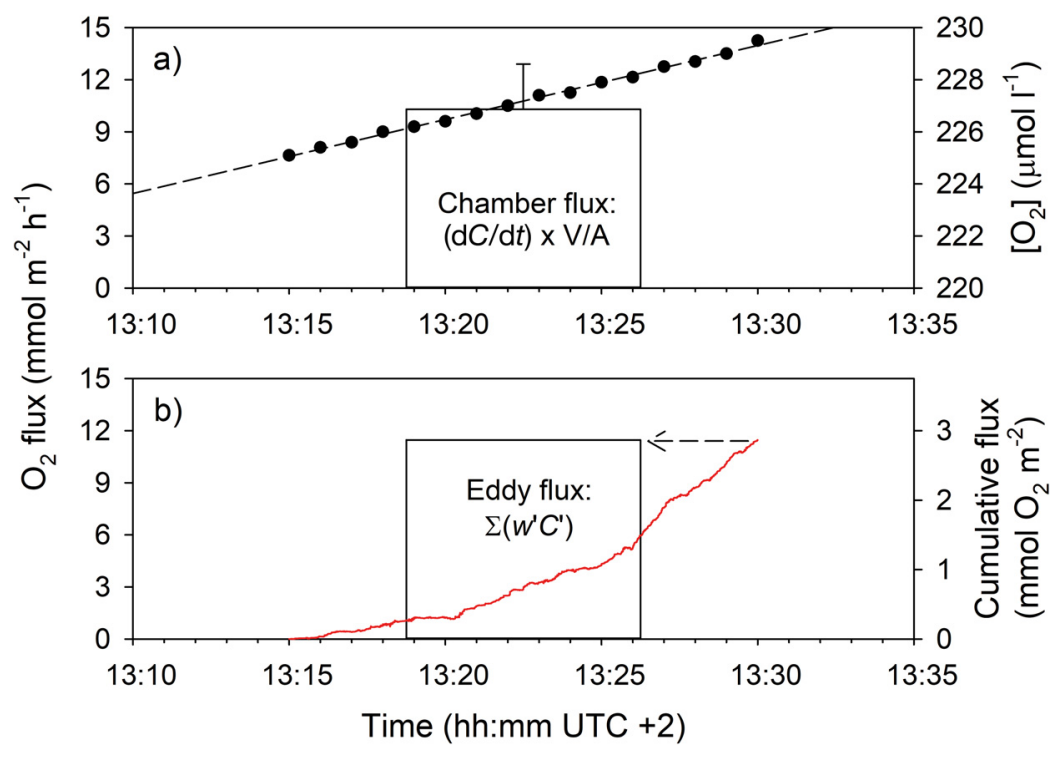

Fig. 2. Example of chamber and eddy fluxes calculation for a 15 min time span on 8 August. (a) For each time burst, the mean $( \pm S D, n=3)$ chamber flux was calculated from the linear changes in $\mathrm{O}_{2}$ concentration over time $(\mathrm{d} C / \mathrm{d} t)$ and the enclosed water volume (V) and sediment area (A). The dashed line shows the fitted linear function $\left(\mathrm{R}^{2}>0.998\right)$. (b) Eddy covariance fluxes were obtained by integrating consecutive instantaneous fluxes (i.e. cumulative flux, red line), in turn obtained from the covariation in $\mathrm{O}_{2}$ concentration $\left(C^{\prime}\right)$ and vertical flow velocity $\left(w^{\prime}\right)$ from the respective running means (see Section 2.3 for details). UTC: universal time coordinate

was mounted onto a sturdy tripod frame designed to minimise hydrodynamic interference (Berg \& Huettel 2008). The 2 microsensors were used simultaneously for inter-comparison (see below) and were oriented with a $60^{\circ}$ angle relative the velocimeter, such that the microsensor tips ( 20 $\mu \mathrm{m}$ diameter $)$ were located $35 \mathrm{~cm}$ above the seafloor $(\sim 20 \mathrm{~cm}$ above the seagrass canopy) and $0.5 \mathrm{~cm}$ away from the velocimeter measuring volume (McGinnis et al. 2011). Photosynthetically active radiation (PAR) and salinity were recorded every minute with a PAR sensor (LI192, Li-Cor) and a saltwater conductivity sensor (Salinity Data Logger U24-002-C, HOBO) located on the eddy frame. In order to monitor the vertical $\mathrm{O}_{2}$ distribution between the eddy microsensors and the seafloor, 3 cross-calibrated $\mathrm{O}_{2}$ optodes (Dissolved Oxygen Logger U26-001, HOBO) were mounted in a vertical array. These optodes were positioned at $35 \mathrm{~cm}$ (i.e. at the same height as the eddy microsensors above the canopy), at $15 \mathrm{~cm}$ (the canopy edge), and at $5 \mathrm{~cm}$ (inside the canopy) above the seafloor, respectively. The eddy instrument was deployed with microelectrode tips facing the predominant water flow direction, and flow velocity and $\mathrm{O}_{2}$ microsensor output were recorded continuously at $32 \mathrm{~Hz}$. The instruments were deployed by divers using a lift bag to carefully lower and position the instrument onto the seafloor.

The 15 min eddy fluxes were extracted from the $32 \mathrm{~Hz}$ data following well-established protocols (Lorrai et al. 2010). In short, the $32 \mathrm{~Hz}$ data were binaveraged to $8 \mathrm{~Hz}$, and for each $15 \mathrm{~min}$ period, the $8 \mathrm{~Hz}$ data for vertical velocity $(w)$ and $\mathrm{O}_{2}$ concentration $(C)$ were detrended using linear regression, and their mean and fluctuating components were determined (Reynolds decomposition). While Clark-type glass sensors produce high-quality eddy covariance data, they are very fragile and subject to sensor drift, as well as jumps and spikes produced by collision of particles with the sensor tip (Berg et al. 2013, Attard et al. 2014). In post-processing, the 2 sensor signals were thus evaluated for their performance throughout each deployment by (1) cross comparison of 15 min means to optode $\mathrm{O}_{2}$ concentrations, (2) point-to-point noise in the $8 \mathrm{~Hz}$ data streams, and (3) linearity of the instantaneous cumulative fluxes for each 15 min flux period. The sensor showing the best characteristics was then used for flux extraction. Eddy fluxes were calculated from the fluctuations of vertical velocity $\left(w^{\prime}\right)$ and $\mathrm{O}_{2}$ concentration $\left(C^{\prime}\right)$ as $\overline{W^{\prime} C^{\prime}}$, where the overbar represents the 15 min timeaveraging window (Fig. 2b). Fluxes were discarded if large jumps or spikes were present in the $8 \mathrm{~Hz}$ data streams of a given $15 \mathrm{~min}$ burst. The $15 \mathrm{~min}_{2}$ fluxes were binned into $1 \mathrm{~h}$ intervals $\left(\mathrm{mmol} \mathrm{O}_{2} \mathrm{~m}^{-2} \mathrm{~h}^{-1}\right)$, and subsequently, fluxes were corrected for the $\mathrm{O}_{2}$ storage beneath the eddy sensors in order to account for $\mathrm{O}_{2}$ production or consumption that is not captured in the turbulent eddy flux measurements (Rheuban et al. 2014). This was done by adding a storage term $\int_{0}^{h} \frac{\mathrm{d} C}{\mathrm{~d} t} h$ to the measured eddy fluxes, where $\frac{\mathrm{d} C}{\mathrm{~d} t}$ is the change in mean $\mathrm{O}_{2}$ concentration over time (in our case, $1 \mathrm{~h}$ ) in the water volume between the seafloor and the eddy measuring height (h) (Rheuban et al. 2014). To overcome problems associated with the typical $\mathrm{O}_{2}$ vertical gradients within dense macrophyte canopies (Long et al. 2015, Koopmans et al. 2020), we accurately resolved the storage term using the optodes at 3 different heights above the seafloor (i.e. 35,15 , and $5 \mathrm{~cm}$ ). The $2 \mathrm{O}_{2}$ sensors located at 15 and $5 \mathrm{~cm}$ from the seafloor were used to define the mean $\mathrm{O}_{2}$ concentration at the 'inside-canopy' zone 
$(0-15 \mathrm{~cm})$, whereas the sensor at $35 \mathrm{~cm}$ resolved the 'above-canopy' $\mathrm{O}_{2}$ variations. Storage terms for each zone were computed and then summed.

The length, width, and seafloor region of maximum flux contribution were estimated from the seabed surface roughness $\left(z_{0}\right)$ and the sensor measurement height $(z)$ using the approach described by (Berg et al. 2007). The $z_{0}$ was computed from the highfrequency $\mathrm{ADV}$ velocity time series as described by Attard et al. (2015). First, the friction velocity $\left(u^{*}\right)$ was computed for each 15 min flux period from complex Reynolds stress measurements by decomposing the 3 velocity components into a mean and deviatory velocity. The $u^{*}$ was calculated as $u^{*}=\left(\overline{u^{\prime} w^{\prime}}{ }^{2}+\overline{v^{\prime} w^{\prime}}\right)^{1 / 4}$, from which $z_{0}$ was calculated assuming law-ofthe-wall scaling as $z_{0}=z \times \exp \left(-k \times \frac{U}{u^{*}}\right)$, where $k$ is the Kármán constant (0.40), and $U$ is the mean flow velocity magnitude measured by the ADV (Berg et al. 2007).

Eddy covariance theory requires co-located measurements of flow velocity and $\mathrm{O}_{2}$ concentration. The finite response time of the $\mathrm{O}_{2}$ sensor and its distance to the ADV measurement volume cause misalignments in the 2 datasets that may necessitate a timeshift correction. We evaluated whether a time shift correction was required for the data in 2 ways: by computing cumulative co-spectra (ogives), and by applying a time-shift correction that seeks the maximum numerical flux for selected periods of data without surface wave signals. This latter consideration was important at our site (shallow depth with short period waves and low flow velocity) because surface wave signals may yield false correlations when seeking the maximum numerical flux (Berg et al. 2015). Indicators of flux dampening (and therefore a need to time-shift data) in the ogives are typically evidenced as a dip in the cospectra at the high-frequency range caused by fluctuations in velocity and $\mathrm{O}_{2}$ concentration that are out of phase (Berg et al. 2016). These features were not evident in our data. Similarly, shifting for maximum numerical flux under periods with no surface waves yielded an increase in the flux magnitude of just $0-2.5 \%$. A time-shift correction was therefore not applied to the data.

\subsection{Hydrodynamics within the benthic boundary layer}

The high-frequency velocity data obtained from the ADV were also used to assess the hydrodynamic conditions within the benthic boundary layer. Mean flow velocity magnitude $(\bar{U})$ was calculated for each 15 min flux period as the sum of streamwise $(u)$ and traverse $(v)$ components, as $\bar{U}=\sqrt{u^{2}+v^{2}}$. We also investigated wave-induced motions, which often dominate the velocity spectrum over shorter time periods of $\sim 1-10$ s of seconds (and thus are not adequately captured in the mean flow velocity measurements described above). To do this, bottom orbital velocities $\left(u_{b r}\right)$ were estimated from the $8 \mathrm{~Hz}$ nearbottom velocity data as $u_{b r}=\sqrt{2\left(\operatorname{var}\left(u^{\prime}\right)+\operatorname{var}\left(v^{\prime}\right)\right)}$ (Wiberg \& Sherwood 2008). Mean velocity was defined as an average velocity over individual wave periods (typically 2-5 s), and fluctuations were calculated as the difference between measured and mean velocities.

In addition to the 3-dimensional flow velocity components, the velocimeter also records the intensity of the received reflections (backscattering strength, units = counts), which is directly proportional to particle concentration and can thus be used to indicate elevated sediment loads in the water due to waveinduced resuspension (Lohrmann 2001, Brand et al. 2010).

\subsection{Data analysis}

The hourly binned benthic $\mathrm{O}_{2}$ fluxes for each $24 \mathrm{~h}$ period of deployment were used to calculate hourly rates of NDP, $\mathrm{R}$, and GPP (all in mmol $\mathrm{O}_{2} \mathrm{~m}^{-2} \mathrm{~h}^{-1}$ ) (Eyre et al. 2011a, Hume et al. 2011). Metabolic rates were calculated using the eddy-corrected $(n=1)$ and the average hourly binned fluxes obtained in each chamber; thus individual chambers fluxes are reported with standard deviation (SD) that expresses the spatial variability $(\mathrm{n}=3)$. For both techniques, NDP and $\mathrm{R}$ were calculated by averaging fluxes obtained during the daytime (PAR $\geq 3 \mu \mathrm{mol} \mathrm{m} \mathrm{m}^{-2} \mathrm{~s}^{-1}$ ) and nighttime periods (PAR $<3 \mu \mathrm{mol} \mathrm{m} \mathrm{m}^{-2} \mathrm{~s}^{-1}$ ), respectively. As PAR inside the flume-chambers was only $6 \%$ lower than that measured outside the chambers, fluxes from the 2 methodologies were evaluated at the same PAR values. Assuming light-independent R, the GPP was then calculated as GPP $=\mathrm{NDP}+|\mathrm{R}|$. Daily GPP and R rates were calculated by multiplying the respective hourly rates for the hours of light and 24, respectively. The net ecosystem metabolism (NEM, in mmol $\mathrm{O}_{2} \mathrm{~m}^{-2} \mathrm{~d}^{-1}$ ) was calculated by integrating the hourly $\mathrm{O}_{2}$ fluxes over $24 \mathrm{~h}$ (Attard et al. 2019a). The NEM provides the metabolic status of the benthic community, with positive values representative of autotrophy (net release of $\mathrm{O}_{2}$ ). 
Due to the occurrence of high-wind conditions (wind observations obtained from the nearest weather station in Hanko Russarö, https://en.ilmatieteenlaitos.fi/), the average metabolic rates were calculated for 3 distinct periods: (1) the initial, quiescent period (calm); (2) the following high-wind period, where winddriven hydrodynamics induced sediment resuspension (resuspension); and (3) the quiescent, post-wind period (resettling). For each of the calm, resuspension, and resettling periods, the hourly binned fluxes were plotted against the PAR data to obtain a P-I curve, which modelled NDP values using a modified Jassby \& Platt (1976) equation:

$$
\mathrm{NDP}=\mathrm{P}_{\mathrm{m}} \tanh \left(\frac{\mathrm{I}}{\mathrm{I}_{k}}\right)-\mathrm{R}
$$

where $\mathrm{P}_{\mathrm{m}}$ is the maximum GPP rate, $\mathrm{I}$ is the hourlyaveraged recorded near-bed irradiance, $\mathrm{I}_{k}$ is the light saturation parameter (both in $\mu$ mol quanta $\mathrm{m}^{-2} \mathrm{~s}^{-1}$ ), and $\mathrm{R}$ is the respiration parameter. The curve fitting was obtained by Levenberg-Marquardt iteration setting, with $\mathrm{P}_{\mathrm{m}}, \mathrm{I}_{k}$, and $\mathrm{R}$ as varying parameters. The compensation irradiance $\left(I_{C}\right)$ was then derived from the P-I curves as the irradiance level at which NDP is 0 . Curve-fitting was performed in OriginPro 7 (OriginLabs).

\subsection{Sediment parameters and biotic sampling}

At the end of each deployment, all macrophyte biomass inside each chamber was sampled and transported to the Tvärminne Zoological Station within $1 \mathrm{~h}$. After species identification and rinsing in freshwater, plant dry weight (DW) was measured by drying at $60^{\circ} \mathrm{C}$ to a constant weight $(>48 \mathrm{~h})$. In addition, sediment samples were taken from just outside the chambers. Triplicate $10 \mathrm{~cm}$ height sediment cores (at each deployment) were sampled using core liners (I.D. $\times$ height; $5.2 \times 30 \mathrm{~cm}$ ), and benthic chlorophyll a (chl a) (at the end of deployment No. 1) using cut-off syringes (I.D. $\times$ height; $3.5 \times 10 \mathrm{~cm}$ ). Sediment samples were either stored in a re-aerated aquarium with in situ seawater (sediment cores) or frozen at $-20^{\circ} \mathrm{C}$ in darkness (chl a samples). Within 2 wk of sampling, benthic chl a was analysed by extracting $1 \mathrm{~g}$ of the homogenised upper $2 \mathrm{~cm}$ sediment in $10 \mathrm{ml}$ ethanol (96.1\% $\mathrm{v} / \mathrm{v})$ for $12 \mathrm{~h}$ in the dark. The chl a concentration was determined spectrophotometrically (Ordior UV-2501 PC, UV-VIS recording spectrophotometer, Shimadzu) at 665 and $750 \mathrm{~nm}$ before and after acidification with $50 \mu \mathrm{l}$ of $2 \mathrm{M} \mathrm{HCl}$ (Castle et al. 2011). Within $2 \mathrm{~d}$ of collection, the sediment permeability was measured in the intact sediment cores by the constant head method (Klute \& Dirksen 1986). Cores were then sliced in $1 \mathrm{~cm}$ layers and weighed before and after subsequent drying at $105^{\circ} \mathrm{C}$ and combustion at $520^{\circ} \mathrm{C}$ until constant weight $(\geq 24 \mathrm{~h})$. The porosity was calculated from the measured density and water content, and the content of organic matter was derived as loss on ignition of dried sediment samples.

\subsection{Laboratory resuspension experiments}

To demonstrate the effects of sediment resuspension on benthic $\mathrm{O}_{2}$ and $\sum_{2} \mathrm{CO}_{2}$ dynamics, we performed a series of laboratory experiments to quantify (1) the oxidized (Fe[III]) and reduced (Fe[II]) particulate iron pools in the sediment and (2) the $\mathrm{O}_{2}$ and $\Sigma \mathrm{CO}_{2}$ flux dynamics associated with resuspension of different sediment layers down to $2.0 \mathrm{~cm}$ depth. All laboratory experiments were conducted under dark conditions. Four unvegetated sediment cores (I.D. $\times$ height; $5.6 \times 30 \mathrm{~cm}$ ) were sampled from the same area and during the same season. After equipping all cores with stirring bars (60 rpm) and allowing the sediment to acclimate for $1 \mathrm{~d}$ at in situ temperature, all cores were incubated to establish their baseline benthic $\mathrm{O}_{2}$ and $\Sigma \mathrm{CO}_{2}$ fluxes. At the beginning and at the end of the incubation, water was extracted from the overlying water using a gas-tight glass syringe, transferred into $12 \mathrm{ml}$ exetainers and spiked with $\mathrm{HgCl}_{2}$ for $\Sigma \mathrm{CO}_{2}$ determination on a flow injection/ diffusion cell analyser (Hall \& Aller 1992). During the incubation, the $\mathrm{O}_{2}$ concentration was monitored at 15 min intervals using contactless sensor spots (OXSP5, PyroScience) fixed on the inner wall of the lids. The benthic $\mathrm{O}_{2}$ and $\Sigma \mathrm{CO}_{2}$ fluxes were calculated from the linear change in concentration data over time, accounting for the enclosed water volume and sediment area (calculation as per Fig. 2a). One sediment core was then sectioned at 3-4 mm intervals for solid phase Fe determination ( $\mathrm{n}=2$ for each sediment depth), while the remaining cores were set aside for the resuspension experiment. Particulate Fe pools were determined spectrophotometrically at $562 \mathrm{~nm}$ after extraction in $5 \mathrm{ml}$ of $0.5 \mathrm{~mol} \mathrm{l}^{-1} \mathrm{HCl}$ (Lovley \& Phillips 1987). Fe(II) was analysed by mixing $40 \mu \mathrm{l}$ of extractant with $2 \mathrm{ml}$ of $0.02 \%$ Ferrozine in $50 \mathrm{mmol} \mathrm{l}^{-1}$ HEPES buffer, while total extractable Fe (Fe[III] + Fe[II]) was determined by adding the Ferrozine reagent and $0.2 \mathrm{ml}$ of $1 \%$ hydroxylamine-hydrochloride (Kristensen et al. 2003). Oxidized Fe(III) was calculated as the difference between total $\mathrm{Fe}$ and $\mathrm{Fe}(\mathrm{II})$. The $\mathrm{O}_{2}$ consumption associated with Fe(II) oxi- 
dation ( $\mathrm{mmol} \mathrm{m}^{-2}$ ) was calculated accounting for the measured sediment weight of each sediment layer and assuming typical reaction stoichiometries of 2.25 $\mathrm{O}_{2}: 1 \mathrm{FeS}$ and $3.5 \mathrm{O}_{2}: 1 \mathrm{FeS}_{2}$ (Aller 2014).

For the resuspension experiment, we explored the $\mathrm{O}_{2}$ and $\Sigma \mathrm{CO}_{2}$ flux dynamics associated with (1) the resuspended sediment in the water and (2) with the newly exposed sediment surface following resuspension of the upper layer. To do this, sediment cores were sliced at approximately $5 \mathrm{~mm}$ intervals from the sediment surface down to a depth of $2.0 \mathrm{~cm}$. After removing each sediment layer, the core was inserted in a mini-flume aquarium (horizontal flow of $0.2 \mathrm{~cm} \mathrm{~s}^{-1}$ ), and the diffusive $\mathrm{O}_{2}$ uptake rate of the newly exposed sediment surface was quantified by measuring $\mathrm{O}_{2}$ microprofiles using a Clark-type microelectrode mounted on a motorized manipulator (MU-1; PyroScience) (Revsbech 1989). The sediment diffusive $\mathrm{O}_{2}$ uptake (DOU) was quantified by measuring $\mathrm{O}_{2}$ microprofiles over a $1 \mathrm{~h}$ period after sectioning $(\mathrm{n}=3-6)$. The DOU was calculated from the linear change in $\mathrm{O}_{2}$ concentration within the diffusive boundary layer by applying Fick's first law (Rasmussen \& Jørgensen 1992). To determine the $\mathrm{O}_{2}$ consumption and $\Sigma \mathrm{CO}_{2}$ production associated with the resuspended particles, $1.5 \mathrm{~g}$ wet weight (WW) of sectioned sediment was incubated in $12 \mathrm{ml}$ exetainers filled with site water and mounted on a rotating plankton wheel (e.g. Glud et al. 2015). To determine the initial $\Sigma \mathrm{CO}_{2}$ concentration, the exetainer slurry was shaken and a $3 \mathrm{ml}$ sample was extracted for $\Sigma \mathrm{CO}_{2}$ measurement. The extracted water volume was replaced with artificial seawater. After sealing, the internal $\mathrm{O}_{2}$ concentration was measured every $30 \mathrm{~min}$ with contactless sensor spots (OXSP5, PyroScience) located inside each vial. The incubation was terminated after $6 \mathrm{~h}$ when the $\mathrm{O}_{2}$ concentration had decreased by $\sim 30 \%$. The incubations were killed using $\mathrm{HgCl}_{2}$ and a final sample was collected for $\mathrm{\Sigma CO}_{2}$ analysis (see above). $\mathrm{O}_{2}$ and $\Sigma \mathrm{CO}_{2}$ fluxes were calculated from the linear change in concentration over time, accounting for measured weight and density of incubated sediment. RQ was calculated for each depth interval of sediment resuspended as the ratio between $\Sigma \mathrm{CO}_{2}$ production and $\mathrm{O}_{2}$ consumption rates.

The $\mathrm{O}_{2}$ flux, $\Sigma \mathrm{CO}_{2}$ flux, and RQ dynamics measured during the sediment resuspension experiments were compared against the baseline fluxes measured in intact sediment cores immediately after sampling acclimation (1-way ANOVA). To calculate the total $\mathrm{O}_{2}$ uptake promoted by resuspension, the DOU at the newly exposed sediment surface was summed with the respective $\mathrm{O}_{2}$ consumption in the resuspended sediment layer. The same procedure was followed to cal- culate the parallel total $\Sigma \mathrm{CO}_{2}$ production during resuspension, except that the $\Sigma \mathrm{CO}_{2}$ exchange at the newly exposed sediment surface was calculated by multiplying the corresponding DOU and RQ values. All data were normally distributed and homoscedastic.

\section{RESULTS}

\subsection{Site characteristics and deployments}

The measured sediment permeability, although functionally impermeable (see Section 2.1), was 11.5 $\pm 3.5 \times 10^{-12} \mathrm{~m}^{2}$ ( $\mathrm{n}=6$ for all values reported in this section), and porosity decreased from $0.44 \pm 0.03$ at the surface to $0.27 \pm 0.05$ at $9.5 \mathrm{~cm}$ depth. The sediment organic matter content rapidly decreased from $1.3 \pm 0.4 \% \mathrm{DW}$ at the surface to $0.8 \pm 0.3 \% \mathrm{DW}$ at $1.5 \mathrm{~cm}$ depth; thereafter, it gradually decreased to 0.3 $\pm 0.1 \% \mathrm{DW}$ at $9.5 \mathrm{~cm}$ depth. The macrophyte biomass was $45.9 \pm 16.9 \mathrm{~g} \mathrm{DW} \mathrm{m}^{-2}$ (Table 1), of which $34.6 \pm 13.6 \mathrm{~g} \mathrm{DW} \mathrm{m}^{-2}$ (or $76 \pm 13 \%$ ) was the eelgrass Zostera marina. This corresponded to an eelgrass density of approximately 233 shoots $\mathrm{m}^{-2}$, as estimated from the average biomass per shoot density at the study site (Boström et al. 2014). Most of the eelgrass biomass $\left(26.0 \pm 12.6 \mathrm{~g} \mathrm{DW} \mathrm{m}^{-2}\right.$, or $\left.73 \pm 8 \%\right)$ was allocated to the aboveground biomass, which formed a canopy with a maximum vertical height of $18-20 \mathrm{~cm}$.

High-quality $\mathrm{O}_{2}$ fluxes were measured for a total of $171 \mathrm{~h}$ with the flume-chambers and for $141 \mathrm{~h}$ by the eddy covariance system. This corresponded to 5 full days ( $24 \mathrm{~h}$ periods) of eddy fluxes and $6 \mathrm{~d}$ of chamber fluxes. Temporal changes in $\mathrm{O}_{2}$ concentration inside the chambers and at different vertical positions on the adjacent eddy frame were generally similar during most of the study (Fig. 3a), thus indicating that the high volume-to-surface area ratio of the chamber design ensured natural conditions for the extended incubation time. During quiescent conditions (i.e. flow $<2.9 \mathrm{~cm} \mathrm{~s}^{-1}$ in Fig. 3b), the $\mathrm{O}_{2}$ recorded at the different vertical positions of the eddy frame deviated by up to $125 \mu \mathrm{mol} \mathrm{l}^{-1}$, and both sensors revealed distinct diel $\mathrm{O}_{2}$ fluctuations in the water above and inside the seagrass canopy. The $\mathrm{O}_{2}$ concentration dynamics showed a distinct response to the hydrodynamic conditions within the benthic boundary layer. For instance, during deployment No. 1, increasing wind speed enhanced bottom orbital velocities from 5 to $>30 \mathrm{~cm} \mathrm{~s}^{-1}$, while the flow velocity averaged over 15 min periods reached maximum values of $9 \mathrm{~cm} \mathrm{~s}^{-1}$ (Table 1, Fig. 3b). Under such conditions, the difference in $\mathrm{O}_{2}$ concentration between the 2 water compartments decreased from 
Table 1. Sediment (porosity and organic matter [OM] averaged for the upper $10 \mathrm{~cm}$ sediment) and environmental characteristics during the side-by-side flume-chambers $(\mathrm{CH})$ and eddy $(\mathrm{EC})$ deployments. Sediment characteristics are reported as mean \pm SD for each deployment, while environmental data are presented as mean \pm SD over each period of the deployments, except the photosynthetically active radiation $(\mathrm{PAR})$ values that show the mean $( \pm \mathrm{SD})$ daily integrated PAR; nd: not determined; na: not applicable

\begin{tabular}{|c|c|c|c|c|}
\hline & \multirow{2}{*}{ Unit } & \multicolumn{2}{|c|}{ Deployment No.1 } & \multirow{2}{*}{$\begin{array}{l}\text { Deployment No.2 } \\
\text { Resettling }\end{array}$} \\
\hline & & Calm & Resuspension & \\
\hline \multicolumn{5}{|l|}{ Sediment } \\
\hline Permeability & $10^{-12} \mathrm{~m}^{2}$ & \multicolumn{2}{|c|}{$9.0 \pm 1.6$} & $13.9 \pm 3.3$ \\
\hline Porosity & & \multicolumn{2}{|c|}{$0.30 \pm 0.05$} & $0.32 \pm 0.05$ \\
\hline $\mathrm{OM}$ & $\%$ & \multicolumn{2}{|c|}{$0.71 \pm 0.15$} & $0.57 \pm 0.22$ \\
\hline Chlorophyll a & $\mu g g^{-1}$ & \multicolumn{2}{|c|}{$15.6 \pm 2.9$} & nd \\
\hline Macrophyte & g DW m ${ }^{-2}$ & \multicolumn{2}{|c|}{$45.9 \pm 20.7$} & $45.9 \pm 16.8$ \\
\hline \multicolumn{5}{|l|}{ Environmental } \\
\hline $\mathrm{CH}$ recording & $\mathrm{h}$ & 33 & 77 & 61 \\
\hline EC recording & $\mathrm{h}$ & 33 & 48 & 60 \\
\hline Photoperiod & $\mathrm{h}$ & 16 & 15 & 15 \\
\hline Daily PAR & mol quanta $\mathrm{m}^{-2} \mathrm{~d}^{-1}$ & $7.9 \pm$ na & $4.1 \pm 0.9$ & $4.6 \pm 0.7$ \\
\hline Backscatter & & $76.3 \pm 3.2$ & $108.7 \pm 6.7$ & $82.8 \pm 2.8$ \\
\hline Flow velocity & $\mathrm{cm} \mathrm{s}^{-1}$ & $1.3 \pm 0.2$ & $5.2 \pm 1.5$ & $1.5 \pm 0.3$ \\
\hline Wind speed & $\mathrm{m} \mathrm{s}^{-1}$ & $6.5 \pm 1.3$ & $9.4 \pm 2.5$ & $3.8 \pm 2.0$ \\
\hline Temperature & ${ }^{\circ} \mathrm{C}$ & $17.1 \pm 0.7$ & $19.3 \pm 1.9$ & $14.3 \pm 1.6$ \\
\hline Salinity & PSU & $5.1 \pm 0.0$ & $5.0 \pm 0.1$ & $5.4 \pm 0.2$ \\
\hline
\end{tabular}

21 to $7 \mu \mathrm{mol} \mathrm{l}^{-1}$ (Fig. 3a), reflecting enhanced vertical water mixing and canopy ventilation. The high wind also induced particle resuspension (visual observations), which increased the water turbidity and reduced the PAR availability (Fig. 3b,c, Table 1).

\subsection{Oxygen storage corrections of eddy flux measurements}

Storage correction of eddy fluxes can be neglected if $\mathrm{O}_{2}$ distribution in

Fig. 3. Overview of the environmental conditions during the side-by-side chamber and eddy deployments in the eelgrass meadow. (a) $\mathrm{O}_{2}$ fluctuations recorded above and inside the eelgrass canopy, as well as inside the benthic chambers (mean $\pm \mathrm{SD}$, $n=3$ ), (b) flow velocity and backscatter (depicting turbidity), and (c) light availability at the seafloor (PAR). Note the dynamic vertical $\mathrm{O}_{2}$ gradient in the water compartments above and inside the seagrass canopy during the quiescent conditions (i.e. flow velocity $<2.9 \mathrm{~cm} \mathrm{~s}^{-1}$ ) and the onset of the winddriven resuspension when flow velocity and backscatter values markedly increased on the night between 8 and 9 August
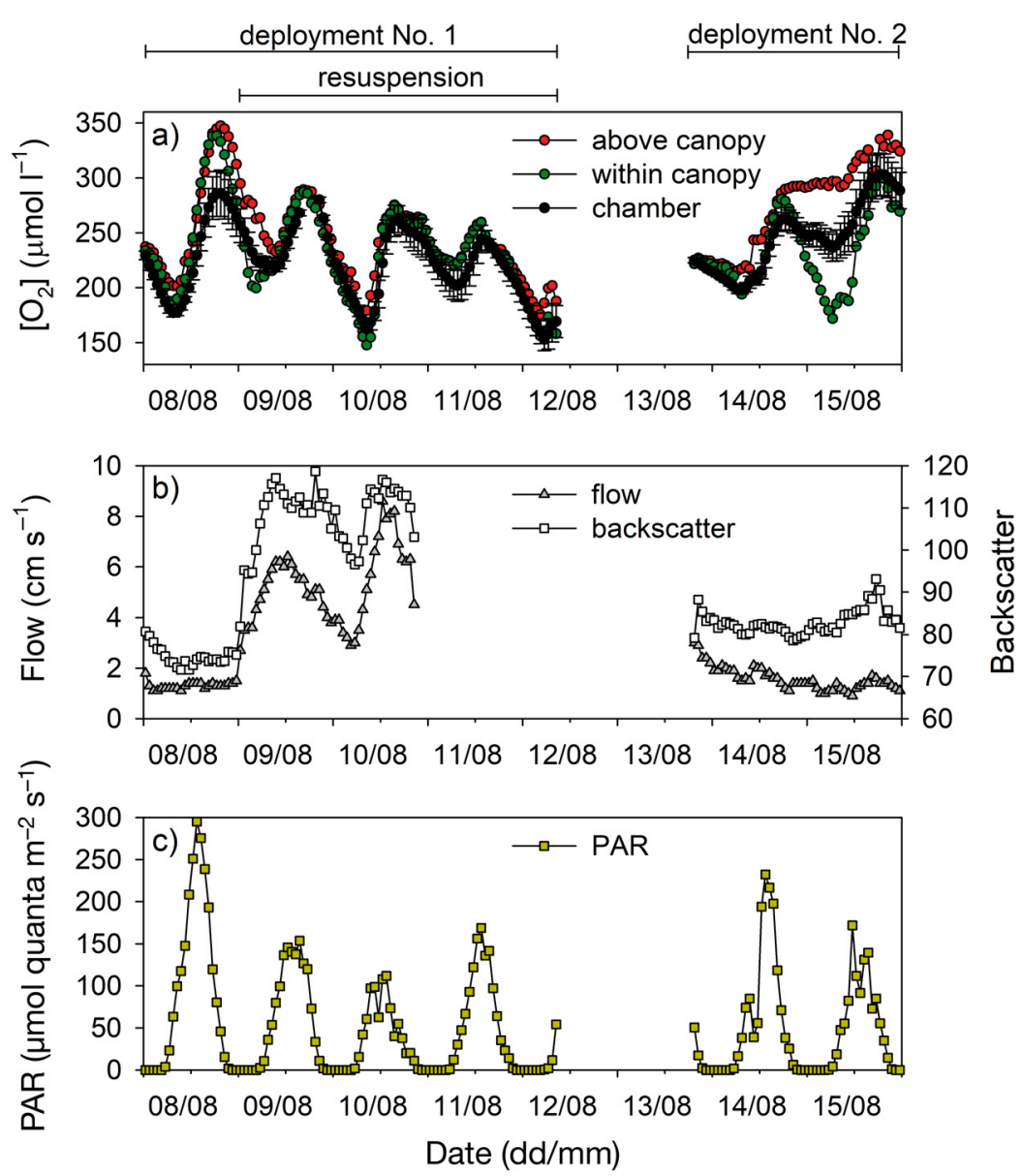
the water volume underneath the recording position remains constant (Berg et al. 2003). However, during our measurements, the mean $\mathrm{O}_{2}$ concentration followed a diel pattern, with fluctuations overall ranging between 8 and $30 \%$ (i.e. $24-77 \mu \mathrm{mol} \mathrm{l}^{-1}$ ) of the daily mean $\mathrm{O}_{2}$ concentration. In combination with a relatively large sensor measurement height of $35 \mathrm{~cm}$, this translated into storage correction terms that substantially increased the magnitude of the hourly fluxes. For example, the storage term typically increased the hourly eddy fluxes by 2 -fold during the calm period (Fig. 4a), whereas the $\mathrm{O}_{2}$ concentrations were relatively more stable during the resuspension period, and here the storage correction only changed the eddy flux by $\sim 10 \%$.

The calculation of the storage term using $\mathrm{O}_{2}$ data from 3 heights above the seafloor was particularly relevant during deployment No. 2, where the $\mathrm{O}_{2}$ fluctuations inside the canopy $(0-15 \mathrm{~cm}$ from the seafloor) were up to $20 \%$ larger than those observed $20 \mathrm{~cm}$ above the canopy (or $35 \mathrm{~cm}$ from the seafloor) (Fig. 3a). Due to such a large vertical $\mathrm{O}_{2}$ gradient developing in the water column below the eddy sen-

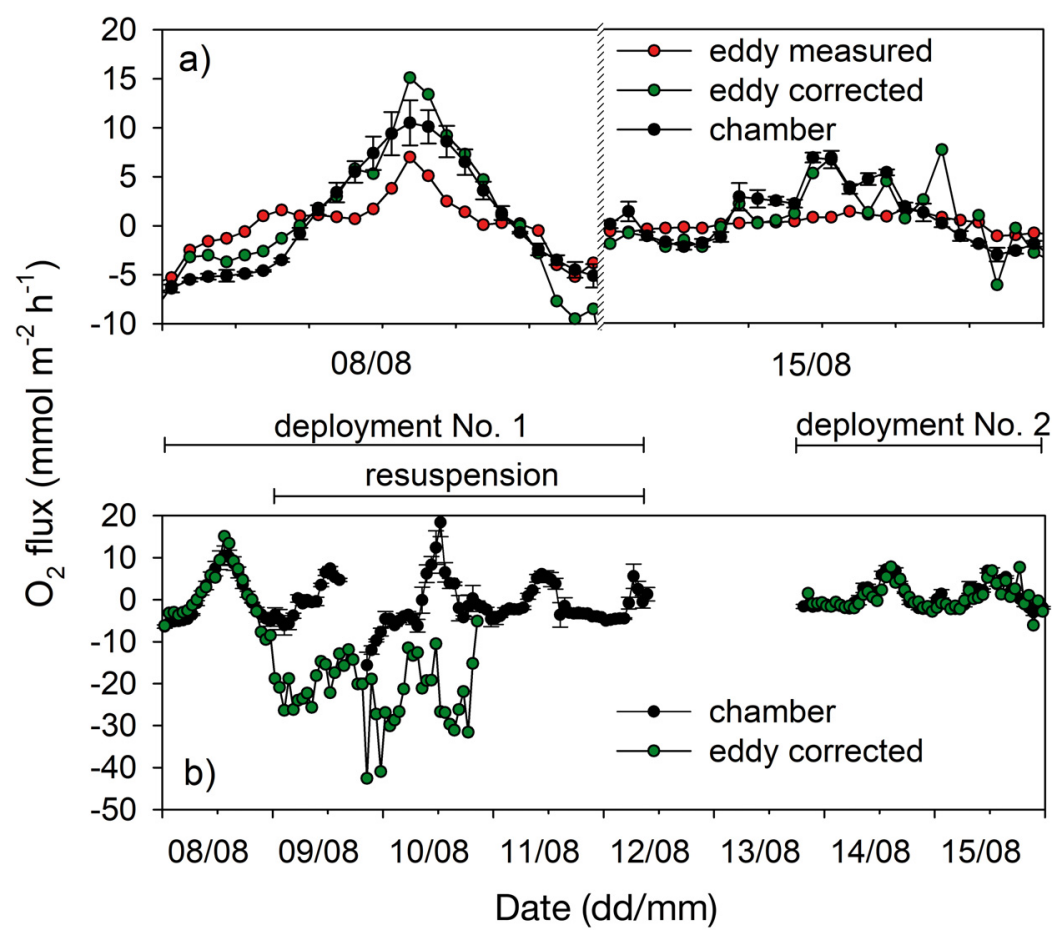

Fig. 4. Benthic $\mathrm{O}_{2}$ fluxes measured during 2 side-by-side chamber and eddy deployments in the eelgrass meadow. (a) Two days of deployment illustrating the influence of the $\mathrm{O}_{2}$ storage term on the measured and corrected eddy fluxes, as compared to those concomitantly measured by the chambers (mean $\pm \mathrm{SD}, \mathrm{n}=3$ ). (b) Overview of entire benthic $\mathrm{O}_{2}$ fluxes dataset highlighting the good agreement between the 2 techniques during quiescent conditions (i.e. periods with flow $<2.9 \mathrm{~cm} \mathrm{~s}^{-1}$ in Fig. $3 \mathrm{~b}$ ), as well as the stimulated eddy $\mathrm{O}_{2}$ uptake rates during the resuspension sors, the corrected eddy fluxes were typically 4 -fold higher than the measured turbulent fluxes during the resettling period (Fig. 4a). Although similar storage corrections to eddy fluxes have already been published (e.g. Rheuban et al. 2014), the remarkably good agreement between chambers and eddy-corrected fluxes measured under quiescent conditions provides further confidence in the practice of storage corrections (Fig. 4b).

\subsection{Temporal flux variations}

During quiescent conditions, the 2 approaches resolved similar benthic $\mathrm{O}_{2}$ fluxes that followed a diel cycle driven by light availability (Fig. 4b). In the initial calm period, the eddy-measured diel $\mathrm{O}_{2}$ flux variations ranged from -13.0 to $15.1 \mathrm{mmol} \mathrm{O}_{2} \mathrm{~m}^{-2} \mathrm{~h}^{-1}$, while the concurrent chamber fluxes ranged from $-7.3 \pm 0.6$ to $10.5 \pm 2.3 \mathrm{mmol} \mathrm{O}_{2} \mathrm{~m}^{-2} \mathrm{~h}^{-1}$ (Fig. 4b) Throughout this period, the chamber and eddy NDP differed by $0.9 \mathrm{mmol} \mathrm{O}_{2} \mathrm{~m}^{-2} \mathrm{~h}^{-1}$ (Table 2), while the chamber NEM $\left(15.7 \mathrm{mmol} \mathrm{O}_{2} \mathrm{~m}^{-2} \mathrm{~d}^{-1}\right)$ was $37 \%$ lower than the eddy-derived value $(24.7 \mathrm{mmol}$ $\mathrm{O}_{2} \mathrm{~m}^{-2} \mathrm{~d}^{-1}$ ). Both approaches, however, provided near-linear relationships between light availability and benthic $\mathrm{O}_{2}$ exchange rates during the calm period (Fig. 5a, Table 2). Overall, these small differences between the 2 techniques presumably reflect spatial variability and/or variations in benthic metabolism driven by complex flow dynamics.

After the initial calm period, the wind-driven increase in flow velocities and wave action induced sediment resuspension. This shift markedly increased the benthic $\mathrm{O}_{2}$ consumption resolved by the eddy fluxes, which fluctuated between -10.5 and $-42.6 \mathrm{mmol}$ $\mathrm{O}_{2} \mathrm{~m}^{-2} \mathrm{~h}^{-1}$ without any distinct diel cycle (Figs. 4b \& 5b). By contrast, the chamber fluxes continued to follow a diel cycle, but due to a $48 \pm 11 \%$ $(\mathrm{n}=3)$ lower light availability in the turbid ambient water, the daytime fluxes decreased to an average of $1.4 \pm$ $1.2 \mathrm{mmol} \mathrm{O}_{2} \mathrm{~m}^{-2} \mathrm{~h}^{-1}$ ( $\mathrm{n}=40$, Fig. 5b, Table 2). The night-time $\mathrm{O}_{2}$ consumption rates in the chambers remained at $-4.4 \pm 1.5 \mathrm{mmol} \mathrm{O}_{2} \mathrm{~m}^{-2} \mathrm{~h}^{-1}(\mathrm{n}=3$, Table 2). After gap-filling $5 \mathrm{~h}$ of miss- 
Table 2. Metabolic rates (net daytime production [NDP], respiration [R], gross primary production [GPP], and net ecosystem metabolism [NEM]) measured by the chamber and eddy techniques for each full $24 \mathrm{~h}$ of deployment. The photosynthesisirradiance $(\mathrm{P}-\mathrm{I})$ parameters (maximum GPP $\left[\mathrm{P}_{\mathrm{m}}\right]$, respiration $[\mathrm{R}]$, light saturation $\left[\mathrm{I}_{k}\right]$, light compensation $\left[\mathrm{I}_{c}\right]$ ) were obtained for each period (calm, resuspension, and resettling) from the fitting curves shown in Fig. 5; na: not applicable

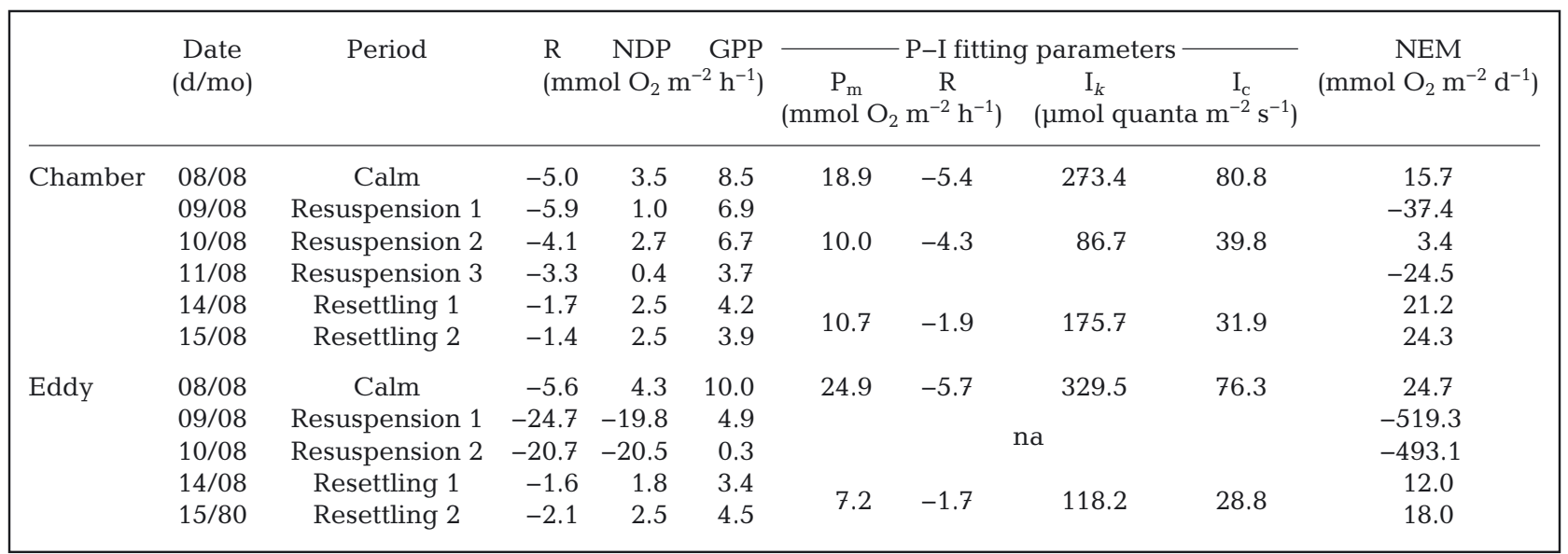

ing chamber fluxes based on the P-I relationship (Fig. 5b), the average NEM resolved during the resuspension period by the chambers $(\mathrm{n}=3)$ and eddy $(\mathrm{n}=2)$ amounted to $-19.5 \pm 20.8$ and $-506.2 \pm$ $18.5 \mathrm{mmol} \mathrm{O}_{2} \mathrm{~m}^{-2} \mathrm{~d}^{-1}$ (Table 2), respectively. Both approaches therefore resolved apparent net heterotrophy during resuspension, but the large difference between the NEM values indicates that the 2 techniques captured very different benthic processes.

As the wind abated, the flow velocities and backscatter signal gradually declined, reflecting the resettling of suspended material (Fig. 3b, Table 1). To capture the effect of resettling on a benthic system that had been exposed to resuspension, all instru-

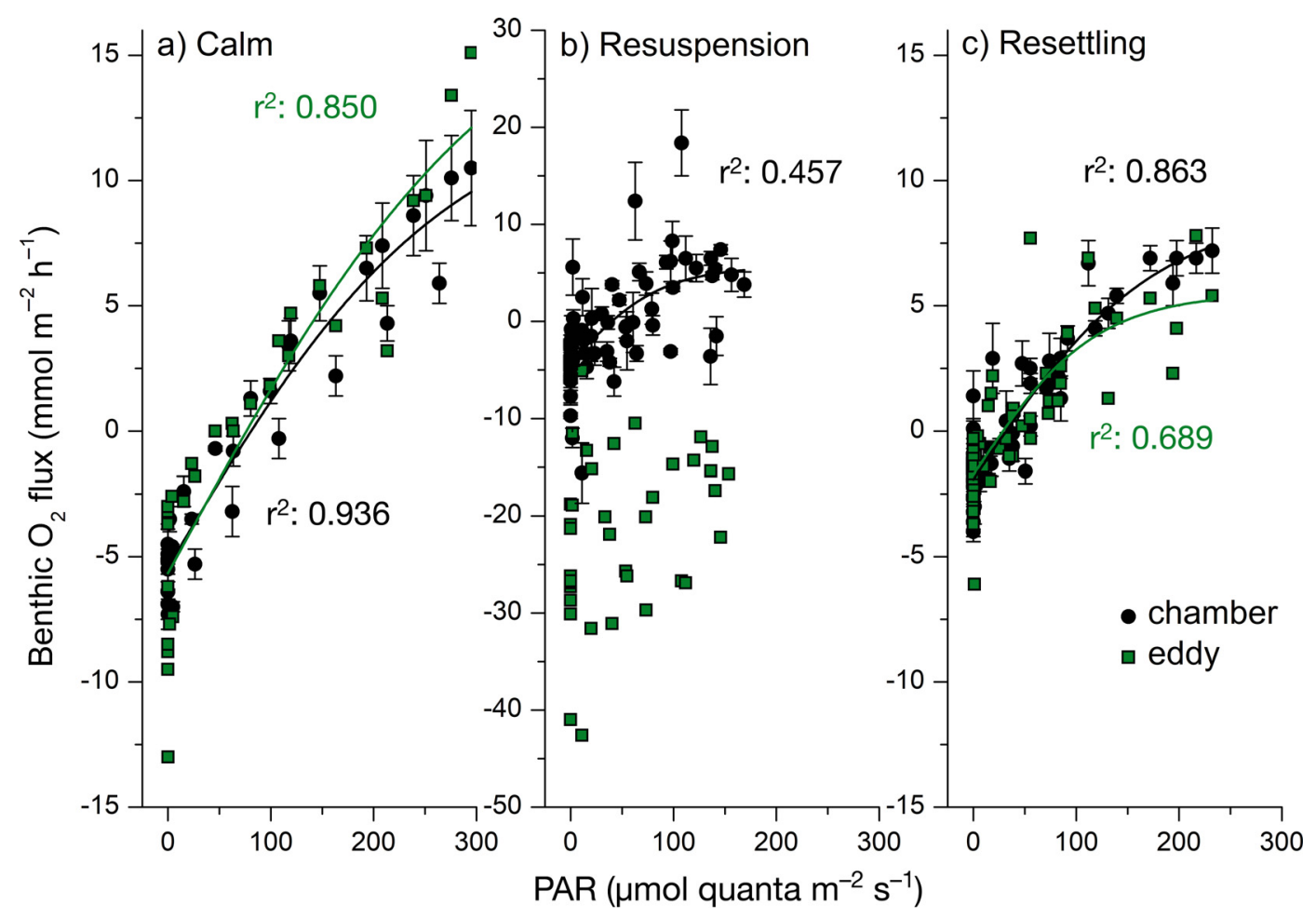

Fig. 5. Variation in the photosynthesis-irradiance relation (Jassby \& Platt 1976) of the eelgrass ecosystem during (a,c) 2 quiescent periods (calm and resettling) interrupted by (b) the occurrence of wind-driven resuspension. For each period, chamber fluxes are reported as mean $\pm \operatorname{SD}(n=3)$ 
ments were redeployed immediately after the resuspension event (deployment No. 2). During the resettling period, the fluxes measured by both techniques converged to similar values exhibiting a strong diel cycle that aligned with the light availability (Fig. 4b). However, the magnitude of hourly chamber and eddy $\mathrm{O}_{2}$ fluxes on average decreased by 49 and $59 \%$, respectively, as compared to the calm period. This suggests that conditions were different during the 2 quiescent periods, as also reflected by the P-I relationships (Fig. 5c, Table 2). For example, the $I_{k}$ and $P_{m}$ values were between 2- and 3-fold lower in the resettling period compared to the calm period (Table 2). Additionally, R rates dropped by $\sim 70 \%$, which translated into a $\sim 3$-fold lower $I_{C}$ during resettling (Table 2).

The natural resuspension dynamics clearly had a large impact on the benthic $\mathrm{O}_{2}$ exchange rates resolved by the 2 techniques, and thus the derived NEM (Table 2). For example, the average chamber NEM for the entire study period amounted to $0.4 \pm$ $25.7 \mathrm{mmol} \mathrm{O}_{2} \mathrm{~m}^{-2} \mathrm{~d}^{-1}(\mathrm{n}=6)$, while the corresponding value for the quiescent periods was $20.4 \pm 4.4 \mathrm{mmol}$
$\mathrm{O}_{2} \mathrm{~m}^{-2} \mathrm{~d}^{-1}(\mathrm{n}=3)$. In contrast, the non-invasive eddy technique provided an average NEM for the entire study period of $-191.5 \pm 287.5 \mathrm{mmol} \mathrm{O}_{2} \mathrm{~m}^{-2} \mathrm{~d}^{-1}(\mathrm{n}=$ 5 ), whereas the value for the quiescent conditions was $18.3 \pm 6.4 \mathrm{mmol} \mathrm{O}_{2} \mathrm{~m}^{-2} \mathrm{~d}^{-1}(\mathrm{n}=3)$. Considering the difference between $\mathrm{O}_{2}$ fluxes measured by enclosure and open-water approaches, it is likely that each methodology captured different effects associated with the resuspension event.

\subsection{Resuspension experiments}

The study area exhibited typical vertical distribution of the solid phase iron pool in coastal sediments, highlighting the gradual accumulation of reduced equivalents such as $\mathrm{Fe}(\mathrm{II})$ below the sediment surface (Fig. 6a). Assuming ferrous iron reacted with $\mathrm{H}_{2} \mathrm{~S}$ and typical reaction stoichiometries (Thamdrup et al. 1994, Aller 2014), the complete oxidation of iron sulphide $(\mathrm{FeS})$ and pyrite $\left(\mathrm{FeS}_{2}\right)$ in the upper $0.5 \mathrm{~cm}$ would correspond to $\mathrm{O}_{2}$ consumption rates of 84.6 and $131.6 \mathrm{mmol} \mathrm{O}_{2} \mathrm{~m}^{-2}$, averaging to $108.1 \mathrm{mmol} \mathrm{O}_{2}$
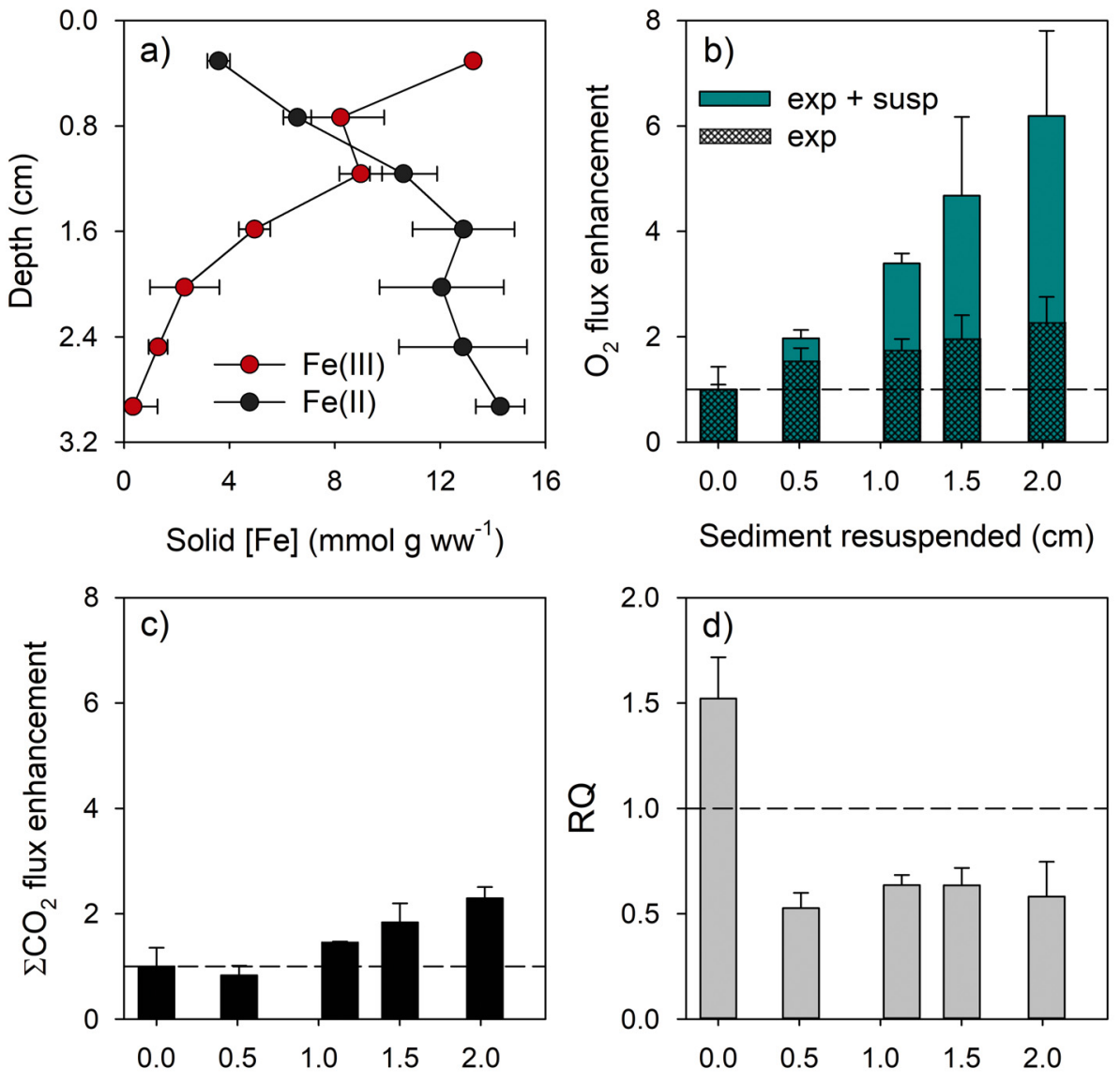

Sediment resuspended $(\mathrm{cm})$

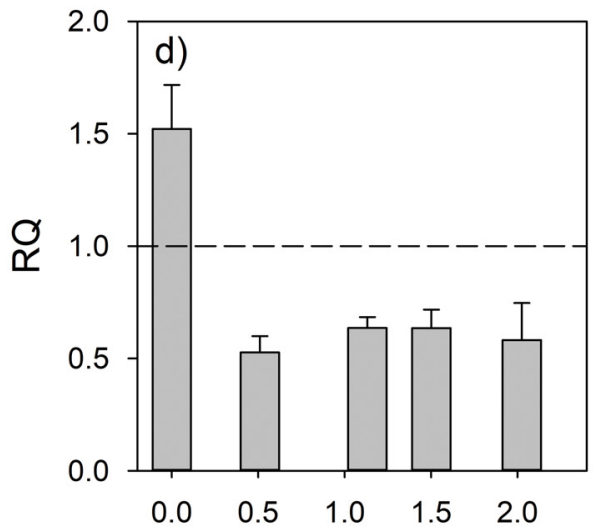

Sediment resuspended $(\mathrm{cm})$
Fig. 6. Effects of sediment resuspension on the benthic $\mathrm{O}_{2}$ and $\Sigma \mathrm{CO}_{2}$ dynamics. (a) Vertical distribution of solid phase ferric and ferrous iron pools in the undisturbed sediment. (b) Enhancement of benthic $\mathrm{O}_{2}$ uptake (exp + susp) driven by sediment resuspended from different depths, highlighting the relative contribution of diffusive $\mathrm{O}_{2}$ uptake at the newly exposed sediment surface (exp). (c) Relative increase in $\Sigma \mathrm{CO}_{2}$ production measured concurrently with $\mathrm{O}_{2}$ consumption associated with suspended sediment, and (d) the resulting respiratory quotient $(\mathrm{RQ})$ values. The horizontal dashed lines depict values of 1.0. All values represent mean $\pm \operatorname{SD}(n=2)$, except for baseline fluxes measured by whole-sediment incubations prior the resuspension experiment $(0.0 \mathrm{~cm}$ sediment resuspended; $\mathrm{n}=4$ ) 
$\mathrm{m}^{-2}$ (i.e. for $\mathrm{FeS}_{\mathrm{x}}$ oxidation). As a result of the increasing $\mathrm{Fe}(\mathrm{II})$ concentration with depth, the full $\mathrm{FeS}_{\mathrm{x}}$ reoxidation in the upper $2 \mathrm{~cm}$ of sediment would require a consumption of $951.4 \mathrm{mmol} \mathrm{O}_{2} \mathrm{~m}^{-2}$.

Combining incubation of resuspended sediment from different depth horizons with microprofile measurements at the newly exposed sediment surface, revealed that resuspension of the upper $0.5 \mathrm{~cm}$ sediment would translate into a 2 -fold increase in benthic $\mathrm{O}_{2}$ consumption (Fig. 6b). This enhanced $\mathrm{O}_{2}$ consumption was equally driven by the resuspended particles and the newly exposed sediment surface. Resuspension of deeper sediment layers gradually increased the relative contribution of suspended sediment to the total enhancement of $\mathrm{O}_{2}$ consumption. Resuspension of the upper $2.0 \mathrm{~cm}$ overall increased the $\mathrm{O}_{2}$ consumption by 6.2 -fold $\left(F_{1,11}=25.373 ; \mathrm{p}<0.001\right)$. In parallel, the $\mathrm{CCO}_{2}$ production rate increased only when sediment was resuspended below a depth of $0.5 \mathrm{~cm}$ and overall never exceeded a 2.3-fold enhancement $\left(F_{1,11}=3.575 ; \mathrm{p}>0.05\right)$ (Fig. 6c). Consequently, the RQ values were consistently below 0.7 during sediment resuspension, thus greatly differing from the RQ of 1.5 resolved before inducing any resuspension $\left(F_{1,11}=\right.$ 100.849; p < 0.001) (Fig. 6d).

\section{DISCUSSION}

\subsection{Insight into benthic $\mathrm{O}_{2}$ fluxes resolved by different approaches}

Since the proof-of-concept study of Berg et al. (2003), the aquatic eddy covariance has become a wellestablished technique and has been applied to a wide range of benthic habitats (Glud et al. 2010, Reimers et al. 2012, Long et al. 2013, Attard et al. 2014). Previous studies have demonstrated that deriving accurate benthic $\mathrm{O}_{2}$ fluxes in dynamic settings may require accounting for variations in the mean $\mathrm{O}_{2}$ concentration within the benthic boundary layer by applying a storage correction term (Rheuban et al. 2014, Koopmans et al. 2020). In this study, the direct chambereddy comparison validated the importance of accurately resolving a storage term accounting for the relative contribution of $\mathrm{O}_{2}$ stored within and above a seagrass canopy. Importantly, the NEM rates also substantially differed depending on the $\mathrm{O}_{2}$ data used to calculate the storage term (see Table S1 in the Supplement at www.int-res.com/articles/suppl/m661 p097_supp.pdf), thus accounting for multiple positions in the water column for the $\mathrm{O}_{2}$ storage correction is essential under similar sampling conditions.
During stable, quiescent conditions, the chambers and eddy techniques resolved similar $\mathrm{O}_{2}$ fluxes (Figs. 4 $\& 5)$, thus providing confidence in both approaches. Despite the relative long incubation time (up to $62 \mathrm{~h}$ ), the high volume to surface area ratio (52 1:0.084 $\mathrm{m}^{2}$ ) of the chambers ensured similar diel $\mathrm{O}_{2}$ variations inside and outside the flume-chambers even in these highly productive settings (Fig. 3a). The high temporal resolution of the $\mathrm{O}_{2}$ measurements and unidirectional, horizontal flow inside the chamber further contributed to the remarkable degree of agreement in metabolic rates when considering the different measurement approaches, which on average differed only by $8 \%$ for GPP and $12 \%$ for R and NEM (11 $\pm 3 \%$ overall). These observations align well with previous studies showing that chamber incubations and eddy covariance provide similar fluxes in homogeneous habitats (Berg et al. 2003, 2009, Attard et al. 2015). The eddy fluxes integrated an elliptical seafloor area of $31.4 \mathrm{~m}^{2}$, as modelled from a $19.7 \mathrm{~m}$ long and $2.0 \mathrm{~m}$ wide footprint (i.e. sediment area contributing to $90 \%$ of the flux). The region of maximum contribution to the eddy fluxes was located $0.6 \mathrm{~m}$ upstream of the instrument and within the meadow boundary, but the location of the eddy footprint oscillated from the eastern to western parts of the meadow following changes in the flow direction. It follows that the eddy fluxes integrated a much larger seafloor area as compared to the chambers, which may have contributed to the small differences in benthic metabolism resolved by the 2 methodologies during quiescent conditions.

On the other hand, exchange rates resolved by the 2 approaches typically differ in complex and dynamic settings (Reimers et al. 2012, Berg et al. 2013, McGinnis et al. 2014, Attard et al. 2015). While increasing the number of chamber incubations can, to some extent, contribute to improve the spatial replication and accuracy of measurements within heterogeneous coastal benthic communities, any enclosure approach inevitably excludes the effects of natural flow conditions. This was particularly true in the present study, which for the first time resolved the implications of wind-driven resuspension for in situ $\mathrm{O}_{2}$ flux dynamics in seagrass habitats. The resolved winddriven hydrodynamics were consistent with those reported for the Baltic Sea, where wind-driven resuspension is commonly observed at both sheltered and deeper $(60 \mathrm{~m})$ coastal settings (Lund-Hansen et al. 1997, Danielsson et al. 2007, Niemistö \& Lund-Hansen 2019). During sediment resuspension, the dark eddy $\mathrm{O}_{2}$ uptake rates were 5-fold higher than the chamber fluxes, and the high $\mathrm{O}_{2}$ consumption rates persisted 
throughout the daytime even when the chambers measured a net benthic $\mathrm{O}_{2}$ efflux from the seafloor driven by seagrass production. Such differences are clearly due to the lack of sediment resuspension within the enclosure approach, thereby resulting in chamber $\mathrm{O}_{2}$ fluxes being relatively similar in magnitude and dynamics to the previous calm period (Fig. 4). Consequently, the main driver of $\mathrm{O}_{2}$ fluxes resolved by the chamber throughout each day of the deployments was the PAR availability, whereas this was the case for the eddy covariance measurements only during quiescent periods. Consistent with the laboratory measurements, the eddy fluxes measured during the resuspension event were largely driven by reoxidation of reduced constituents in the suspended material and, to a lower extent, in the newly exposed and reduced sediment layers. Owing to the lack of well-defined boundaries, we cannot exclude the contribution of material resuspended from outside the eddy footprint to the elevated $\mathrm{O}_{2}$ uptake rates resolved during the resuspension period. However, the low eddy measuring height $(35 \mathrm{~cm})$ relative to the water column $(3.5 \mathrm{~m})$, and the complex waveinduced flow conditions rather than unidirectional tidal flows, overall suggest that eddy fluxes were mainly influenced by sediment resuspended within the integrated footprint area.

Organic carbon mineralization in coastal environments typically is dominated by sulphate $\left(\mathrm{SO}_{4}{ }^{2-}\right)$ reduction (Canfield 1993, Jørgensen \& Kasten 2006, Marbà et al. 2007), which leads to the accumulation of $\mathrm{H}_{2} \mathrm{~S}, \mathrm{FeS}$, and $\mathrm{FeS}_{2}$ in anoxic sediment layers. This is particularly true for seagrass sediment (Holmer et al. 2001, Eyre et al. 2011b), and thus the elevated $\mathrm{O}_{2}$ uptake rates resolved by the eddy are likely explained by the oxidation of ferrous iron (e.g. $\mathrm{FeS}_{\mathrm{x}}$ ). Resuspension highly stimulated $\mathrm{O}_{2}$ consumption associated with particles suspended in the water column and the newly exposed sediment surface, which might be partly ascribed to a stimulation of benthic respiration, for example, through the release of organic material from the anoxic sediment to oxic environments (Hulthe et al. 1998). However, the enhanced $\mathrm{O}_{2}$ uptake during resuspension experiments followed patterns in benthic $\mathrm{Fe}(\mathrm{II})$ distribution and theoretical oxidation, thereby aligning with the measured RQ values of 0.6 during resuspension. Compared to the first in situ deployment, the laboratory experiments were performed on sediment cores which likely had lower reduced equivalents due to the absence of seagrass and the exposure to relatively dynamic flow conditions prior to sampling.
Despite the different sediment characteristics, the similar benthic $\mathrm{O}_{2}$ dynamics resolved by laboratory and in situ eddy measurements overall indicate that resuspension largely stimulated the reoxidation of benthic reduced constituents such as $\mathrm{FeS}_{\mathrm{x}}$. It follows that the $\mathrm{O}_{2}$ flux dynamics during resuspension do not directly relate to concurrent biological activity and carbon turnover, but rather reflect the imbalance between mineralization and reoxidation processes in the sediment prior to the resuspension event. In other words, the benthic $\mathrm{O}_{2}$ exchange rate during resuspension partially reflects the carbon turnover of the previous, but undefined, quiescent period. A similar time-lag between benthic $\mathrm{O}_{2}$ dynamics and carbon turnover is also observed in protected coastal sediments, although this tends to occur on longer seasonal time scales. Here, reduced compounds accumulating during summer (i.e. $\mathrm{RQ}>1$ ) are oxidized in winter (i.e. $\mathrm{RQ}<1$ ) as sedimentation rates decrease and $\mathrm{O}_{2}$ availability in bottom water increases (Ferguson et al. 2007, Glud 2008). The resulting seasonal variation in the benthic $\mathrm{O}_{2}$ uptake rate is relatively small compared to the extensive short-term variation in the carbon mineralization rate (Therkildsen \& Lomstein 1993, Glud et al. 2003), but the annual RQ value tends toward approximately 1 (Eyre et al. 2011a). In addition to this seasonal pattern, dynamic coastal environments experience resuspension events (Danielsson et al. 2007), whereby the oxidation of reduced benthic constituents is enhanced by exposing suspended material and reduced sediment layers to elevated $\mathrm{O}_{2}$ concentrations (Fig. 7).

For highly permeable sediments, elevated flow velocities encountered during resuspension can furthermore result in the storage and later consumption of $\mathrm{O}_{2}$ advected into the sediment (Cook et al. 2007, McGinnis et al. 2014). This would lead to suppressed benthic $\mathrm{O}_{2}$ uptake rates in any quiescent period following resuspension, with shifts from anaerobic to aerobic benthic biogeochemical processes for periods of days to weeks (Cook et al. 2007). Although sediment was functionally impermeable, the $\mathrm{O}_{2}$ fluxes resolved during the calm and resettling periods do not necessarily reflect changes in the metabolic rates of seagrass. For example, accounting for the change in temperature between these 2 periods (Table 1) and a $Q_{10}$ value of 1.8 for a temperate seagrass community (Berg et al. 2019), the theoretical $\mathrm{R}$ rate during resettling was estimated to be 2 -fold higher than that actually measured by both techniques. Such biases would propagate into the P-I relationships derived from the $\mathrm{O}_{2}$ fluxes and thus should be interpreted with care. The $\mathrm{O}_{2}$ flux dynam- 


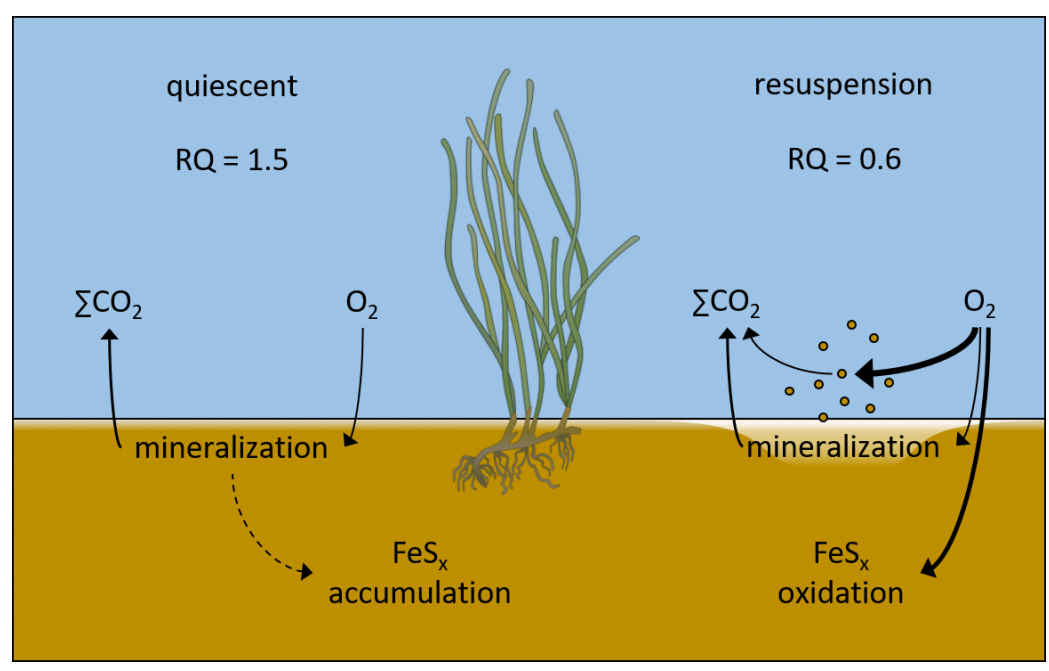

Fig. 7. Conceptual diagram of the effects of resuspension on benthic $\mathrm{O}_{2}$ exchange in seagrass sediment (oxic sediment is shown in white). During summertime quiescent periods, $\mathrm{O}_{2}$ consumption is mainly driven by benthic aerobic metabolism, while iron sulphide (e.g. $\mathrm{FeS}_{\mathrm{x}}$ ) produced during anaerobic mineralization accumulates in the anoxic sediment (i.e. $R Q=1.5$ ). Resuspension events correct this imbalance by fast-tracking reoxidation processes, thus resulting in benthic $\mathrm{O}_{2}$ consumption temporarily uncoupled from the concurrent mineralization rate (i.e. $R Q=0.6$ ). Seagrass illustration from the Integration and Application Network, University of Maryland Center for Environmental Science (ian.umces.edu/imagelibrary/)

ics as resolved by the 2 approaches therefore highlight the importance of adequately accounting for natural variation in key drivers to assess long-term benthic carbon turnover and metabolism at the habitat scale using $\mathrm{O}_{2}$ measurements.

\subsection{Implications of resuspension for carbon cycling assessments}

The metabolic rates resolved during quiescent conditions compare well with those previously measured by eddy covariance and incubation approaches in seagrass meadows (Table S2). The measurements during the initial calm period suggest that the seagrass community was at a quasi-steady state, and well acclimated to relatively high light availability. This is inferred by the relatively low $\mathrm{P}_{\mathrm{m}} / \mathrm{I}_{k}$ ratio (i.e. photosynthetic efficiency) and high light saturation level (Libes 1986, Lee et al. 2007). Indeed, prior to our measuring campaign, the weather conditions had been unusually stable for 45 consecutive days of quiescent conditions. However, the metabolic rates resolved during the period of resuspension clearly stands out from current global estimates (Middelburg et al. 2005, Duarte et al. 2010), implying that periods of resuspension are poorly represented. This is presumably due to the technical challenges of conducting such measurements, but sediment resuspension is an intrinsic component of healthy seagrass communities (Koch 1999), where resuspension contributes to $68-85 \%$ of the annual particle deposition rate (Dauby et al. 1995, Gacia \& Duarte 2001, Paladini de Mendoza et al. 2018). It is therefore important to correctly account for the effect of resuspension on benthic metabolism and carbon turnover as derived from $\mathrm{O}_{2}$ fluxes. For example, based on the respective NEM (Table 2) and RQ values (Fig. 7), the chamber and eddy NEM amounted to -17 and $-824 \mathrm{mmol} \mathrm{C} \mathrm{m}^{-2}$, respectively, over the 6 full days of measurements. Considering the captured resuspension event had a duration of $3 \mathrm{~d}$ and followed a prolonged quiescent period, the upscaled monthly NEM resolved by the chamber and eddy approaches amount to 580.0 and $7.7 \mathrm{mmol} \mathrm{C} \mathrm{m}^{-2}$, respectively. However, the effects of resuspension on benthic $\mathrm{O}_{2}$ and $\Sigma \mathrm{CO}_{2}$ dynamics (and NEM) likely depend on the frequency and duration of resuspension events; therefore, these data cannot be extrapolated to calculate NEM over long time-scales (e.g. season) or be used for different locations. Despite this limitation, it is clear that the best estimates of NEM in dynamic coastal settings should adequately integrate the natural frequency and duration of resuspension events. According to the local weather station (Hanko Russarö), the conditions observed during the resuspension are common in this area, occurring on average every $9 \mathrm{~d}$, and typically persist for a duration of $2 \mathrm{~d}$ in summer (Fig. S1). This highlights the importance of fully including such dynamic conditions when assessing coastal biogeochemical functions at settings similar to our study site. This is especially relevant in seagrass meadows, which represent a hotspot for particle deposition, and where shifts in flow conditions can strongly affect dynamics of suspended matter concentrations and closely associated biogeochemical processes.

Shifts in benthic metabolic rates are typically related to complex changes in light availability and flow velocity, and disentangling the main drivers of benthic metabolism under in situ conditions remains challenging. For instance, reduced light availability during resuspension reduced the seagrass productiv- 
ity inside the chambers (Tables 1 \& 2). However, comparison of the NEM rates resolved by the 2 techniques during resuspension (Table 2) indicate that the decrease in seagrass productivity only accounted for $4 \%$ of the apparent NEM resolved by the eddy during resuspension. During summer, the metabolic balance of the investigated eelgrass community therefore oscillated between net autotrophy and heterotrophy depending on the occurrence of resuspension. This is in contrast with previous temporal patterns resolved for seagrass communities, which mainly focus on seasonal changes in the metabolic balance (Rheuban et al. 2014, Attard et al. 2019b, Berg et al. 2019). The present database might overestimate the actual NEM of seagrass communities, as resuspension is not sufficiently accounted for. Future studies should adopt techniques that account for the effects of resuspension in order to assess the biogeochemical functioning of seagrass ecosystems. Particularly, this study highlights the importance of undertaking $\mathrm{O}_{2}$ flux measurements under appropriate timescales and in parallel with determination of $\mathrm{RQ}$ ratios in order to evaluate the carbon turnover and sequestration at the ecosystem scale under dynamic flow conditions.

Acknowledgements. We are grateful to our colleagues at the Tvärminne Zoological Station for providing access to the field station. In particular, Joanna Norkko, Alf Norkko, Iván Rodil, and Charlotte Angove facilitated fieldwork and logistics and helped with species identification. Anni Glud at the University of Southern Denmark constructed the oxygen microsensors and assisted during the resuspension experiments. This study utilized research infrastructure facilities provided by the Finnish Marine Research Infrastructure network (FINMARI, The Academy of Finland, project ID 283417). The Walter and Andrée de Nottbeck Foundation supported this work through a postdoctoral fellowship to K.M.A. and through a senior research fellowship to R.N.G. The work was furthermore supported by the Danish National Research Council (FNU 7014-00078), The Academy of Finland (project ID 294853), the European Commission through HADES-ERC (project ID 669947), the Danish National Research Foundation through the Danish Center for Hadal Research (HADAL, Grant no. DNRF145), and the Australian Research Council (DP160100248).

\section{LITERATURE CITED}

Aller RC (2014) Sedimentary diagenesis, depositional environments, and benthic fluxes. In: Holland $\mathrm{H}$, Turekian KK (eds) Treatise on geochemistry, $2^{\text {nd }}$ edn. Elsevier, Oxford, p 293-334

Almroth E, Tengberg A, Andersson JH, Pakhomova S, Hall POJ (2009) Effects of resuspension on benthic fluxes of oxygen, nutrients, dissolved inorganic carbon, iron and manganese in the Gulf of Finland, Baltic Sea. Cont Shelf Res 29:807-818
Attard KM, Glud RN, McGinnis DF, Rysgaard S (2014) Seasonal rates of benthic primary production in a Greenland fjord measured by aquatic eddy correlation. Limnol Oceanogr 59:1555-1569

Attard KM, Stahl H, Kamenos NA, Turner G, Burdett HL, Glud RN (2015) Benthic oxygen exchange in a live coralline algal bed and an adjacent sandy habitat: an eddy covariance study. Mar Ecol Prog Ser 535:99-115

Attard KM, Rodil IF, Berg P, Norkko J, Norkko A, Glud RN (2019a) Seasonal metabolism and carbon export potential of a key coastal habitat: the perennial canopy-forming macroalga Fucus vesiculosus. Limnol Oceanogr 64: 149-164

Attard KM, Rodil IF, Glud RN, Berg P, Norkko J, Norkko A (2019b) Seasonal ecosystem metabolism across shallow benthic habitats measured by aquatic eddy covariance. Limnol Oceanogr Lett 4:79-86

Berg P, Huettel M (2008) Monitoring the seafloor using the noninvasive eddy correlation technique: integrated benthic exchange dynamics. Oceanography 21:164-167

* Berg P, Røy H, Janssen F, Meyer V, Jørgensen BB, Huettel M, De Beer D (2003) Oxygen uptake by aquatic sediments measured with a novel non-invasive eddy-correlation technique. Mar Ecol Prog Ser 261:75-83

* Berg P, Røy H, Wiberg PL (2007) Eddy correlation flux measurements: the sediment surface area that contributes to the flux. Limnol Oceanogr 52:1672-1684

* Berg P, Glud RN, Hume A, Stahl H, Oguri K, Meyer V, Kitazato $H$ (2009) Eddy correlation measurements of oxygen uptake in deep ocean sediments. Limnol Oceanogr Methods 7:576-584

* Berg P, Long MH, Huettel M, Rheuban JE and others (2013) Eddy correlation measurements of oxygen fluxes in permeable sediments exposed to varying current flow and light. Limnol Oceanogr 58:1329-1343

* Berg P, Reimers CE, Rosman JH, Huettel M, Delgard ML, Reidenbach MA, Özkan-Haller HT (2015) Technical note: Time lag correction of aquatic eddy covariance data measured in the presence of waves. Biogeosciences 12:6721-6735

* Berg P, Koopmans DJ, Huettel M, Li H, Mori K, Wüest A (2016) A new robust oxygen-temperature sensor for aquatic eddy covariance measurements. Limnol Oceanogr Methods 14:151-167

*Berg P, Delgard ML, Polsenaere P, McGlathery KJ, Doney SC, Berger AC (2019) Dynamics of benthic metabolism, $\mathrm{O}_{2}$, and $\mathrm{pCO}_{2}$ in a temperate seagrass meadow. Limnol Oceanogr 64:2586-2604

Booij K, Helder W, Sundby B (1991) Rapid distribution of oxygen in a sandy sediment induced by changes in the flow velocity of the overlying water. Neth J Sea Res 28: 149-165

* Boström C, Baden S, Bockelmann AC, Dromph K and others (2014) Distribution, structure and function of Nordic eelgrass (Zostera marina) ecosystems: implications for coastal management and conservation. Aquat Conserv 24:410-434

Brand A, Lacy JR, Hsu K, Hoover D, Gladding S, Stacey MT (2010) Wind-enhanced resuspension in the shallow waters of South San Francisco Bay: mechanisms and potential implications for cohesive sediment transport. J Geophys Res 115:C11024

Canfield DE (1993) Organic matter oxidation in marine sediments. In: Wollast R, Mackenzie FT, Chou L (eds) Interactions of $\mathrm{C}, \mathrm{N}, \mathrm{P}$ and $\mathrm{S}$ biogeochemical cycles and 
global change. NATO ASI Series (Series I: Global Environmental Change), Vol 4. Springer, Berlin, p 333-363

* Castle SC, Morrison CD, Barger NN (2011) Extraction of chlorophyll a from biological soil crusts: a comparison of solvents for spectrophotometric determination. Soil Biol Biochem 43:853-856

Chipman L, Berg P, Huettel M (2016) Benthic oxygen fluxes measured by eddy covariance in permeable Gulf of Mexico shallow-water sands. Aquat Geochem 22:529-554

Cook PLM, Wenzhöfer F, Glud RN, Janssen F, Huettel M (2007) Benthic solute exchange and carbon mineralization in two shallow subtidal sandy sediments: effects of advective pore-water exchange. Limnol Oceanogr 52: 1943-1963

Dahl M, Infantes E, Clevesjö R, Linderholm HW, Björk M, Gullström M (2018) Increased current flow enhances the risk of organic carbon loss from Zostera marina sediments: insights from a flume experiment. Limnol Oceanogr 63: 2793-2805

Danielsson A, Jönsson A, Rahm L (2007) Resuspension patterns in the Baltic proper. J Sea Res 57:257-269

* Dauby P, Bale AJ, Bloomer N, Canon C and others (1995) Particle fluxes over a Mediterranean seagrass bed: a one year case study. Mar Ecol Prog Ser 126:233-246

* Duarte CM, Middelburg JJ, Caraco N (2005) Major role of marine vegetation on the oceanic carbon cycle. Biogeosciences 2:1-8

Duarte CM, Borum J, Short FT, Walker DI (2008) Seagrass ecosystems: their global status and prospects. In: Polunin NVC (ed) Aquatic ecosystems: trends and global prospects. Cambridge University Press, Cambridge, p 281-294

* Duarte CM, Marbà N, Gacia E, Fourqurean JW, Beggins J, Barrón C, Apostolaki ET (2010) Seagrass community metabolism: assessing the carbon sink capacity of seagrass meadows. Global Biogeochem Cycles 24:GB4032

Eyre BD, Ferguson AJP, Webb A, Maher D, Oakes JM (2011a) Metabolism of different benthic habitats and their contribution to the carbon budget of a shallow oligotrophic sub-tropical coastal system (southern Moreton Bay, Australia). Biogeochemistry 102:87-110

Eyre BD, Maher D, Oakes JM, Erler DV, Glasby TM (2011b) Differences in benthic metabolism, nutrient fluxes, and denitrification in Caulerpa taxifolia communities compared to uninvaded bare sediment and seagrass (Zostera capricorni) habitats. Limnol Oceanogr 56: $1737-1750$

Eyre BD, Maher DT, Squire P (2013) Quantity and quality of organic matter (detritus) drives $\mathrm{N}_{2}$ effluxes (net denitrification) across seasons, benthic habitats, and estuaries. Global Biogeochem Cycles 27:1083-1095

Fenchel T, Glud RN (2000) Benthic primary production and $\mathrm{O}_{2}-\mathrm{CO}_{2}$ dynamics in a shallow-water sediment: spatial and temporal heterogeneity. Ophelia 53:159-171

F Ferguson A, Eyre B, Gay J, Emtage N, Brooks L (2007) Benthic metabolism and nitrogen cycling in a sub-tropical coastal embayment: spatial and seasonal variation and controlling factors. Aquat Microb Ecol 48:175-195

Forsberg PL, Ernstsen VB, Andersen TJ, Winter C, Becker M, Kroon A (2018) The effect of successive storm events and seagrass coverage on sediment suspension in a coastal lagoon. Estuar Coast Shelf Sci 212:329-340

Fourqurean JW, Duarte CM, Kennedy H, Marbà N and others (2012) Seagrass ecosystems as a globally significant carbon stock. Nat Geosci 5:505-509
Gacia E, Duarte CM (2001) Sediment retention by a Mediterranean Posidonia oceanica meadow: the balance between deposition and resuspension. Estuar Coast Shelf Sci 52:505-514

Glud RN (2008) Oxygen dynamics of marine sediments. Mar Biol Res 4:243-289

Glud RN, Forster S, Huettel M (1996) Influence of radial pressure gradients on solute exchange in stirred benthic chambers. Mar Ecol Prog Ser 141:303-311

Glud RN, Gundersen JK, Røy H, Jørgensen BB (2003) Seasonal dynamics of benthic $\mathrm{O}_{2}$ uptake in a semienclosed bay: importance of diffusion and faunal activity. Limnol Oceanogr 48:1265-1276

Flud RN, Berg P, Hume A, Batty P, Blicher ME, Lennert K, Rysgaard S (2010) Benthic $\mathrm{O}_{2}$ exchange across hard-bottom substrates quantified by eddy correlation in a subArctic fjord. Mar Ecol Prog Ser 417:1-12

* Glud RN, Grossart HP, Larsen M, Tang KW and others (2015) Copepod carcasses as microbial hot spots for pelagic denitrification. Limnol Oceanogr 60:2026-2036

* Gruber RK, Lowe RJ, Falter JL (2017) Metabolism of a tidedominated reef platform subject to extreme diel temperature and oxygen variations. Limnol Oceanogr 62: 1701-1717

*Gundersen JK, Ramsing NB, Glud RN (1998) Predicting the signal of $\mathrm{O}_{2}$ microsensors from physical dimensions, temperature, salinity, and $\mathrm{O}_{2}$ concentrations. Limnol Oceanogr 43:1932-1937

*Hall POJ, Aller RC (1992) Rapid, small-volume, flow injection analysis for $\Sigma \mathrm{CO}_{2}$ and $\mathrm{NH}_{4}{ }^{+}$in marine and freshwaters. Limnol Oceanogr 37:1113-1119

* Hendriks IE, Sintes T, Bouma TJ, Duarte CM (2008) Experimental assessment and modeling evaluation of the effects of the seagrass Posidonia oceanica on flow and particle trapping. Mar Ecol Prog Ser 356:163-173

*Holmer M, Andersen FØ, Nielsen SL, Boschker HTS (2001) The importance of mineralization based on sulfate reduction for nutrient regeneration in tropical seagrass sediments. Aquat Bot 71:1-17

* Huettel M, Gust G (1992) Solute release mechanisms from confined sediment cores in stirred benthic chambers and flume flows. Mar Ecol Prog Ser 82:187-197

*Hulthe G, Hulth S, Hall POJ (1998) Effect of oxygen on degradation rate of refractory and labile organic matter in continental margin sediments. Geochim Cosmochim Acta 62:1319-1328

* Hume AC, Berg P, McGlathery KJ (2011) Dissolved oxygen fluxes and ecosystem metabolism in an eelgrass (Zostera marina) meadow measured with the eddy correlation technique. Limnol Oceanogr 56:86-96

Jassby AD, Platt T (1976) Mathematical formulation of the relationship between photosynthesis and light for phytoplankton. Limnol Oceanogr 21:540-547

Jørgensen BB, Kasten S (2006) Sulfur cycling and methane oxidation. In: Schulz HD, Zabel M (eds) Marine geochemistry. Springer, Berlin, p 271-309

Klute A, Dirksen C (1986) Hydraulic conductivity and diffusivity: laboratory methods. In: Klute A (ed) Methods of soil analysis, Part 1: Physical and mineralogical methods. American Society of Agronomy, Madison, WI, p 687-734

Koch EW (1999) Sediment resuspension in a shallow Thalassia testudinum Banks ex König bed. Aquat Bot 65: 269-280

Koopmans D, Holtappels M, Chennu A, Weber M, de Beer D (2020) High net primary production of Mediterranean 
seagrass (Posidonia oceanica) meadows determined with aquatic eddy covariance. Front Mar Sci 7:118

Kristensen E, Kristiansen KD, Jensen MH (2003) Temporal behaviour of manganese and iron in a sandy coastal sediment exposed to water column anoxia. Estuaries 26: 690-699

Lee KS, Park SR, Kim YK (2007) Effects of irradiance, temperature, and nutrients on growth dynamics of seagrasses: a review. J Exp Mar Biol Ecol 350:144-175

Libes M (1986) Productivity-irradiance relationship of Posidonia oceanica and its epiphytes. Aquat Bot 26:285-306

Lohrmann A (2001) Monitoring sediment concentration with acoustic backscattering instrument. Nortek Tech Note 3: $1-5$

Long MH, Berg P, de Beer D, Zieman JC (2013) In situ coral reef oxygen metabolism: an eddy correlation study. PLOS ONE 8:e58581

Long MH, Berg P, McGlathery KJ, Zieman JC (2015) Subtropical seagrass ecosystem metabolism measured by eddy covariance. Mar Ecol Prog Ser 529:75-90

Lorrai C, McGinnis DF, Berg P, Brand A, Wüest A (2010) Application of oxygen eddy correlation in aquatic systems. J Atmos Ocean Technol 27:1533-1546

KLovley DR, Phillips EJP (1987) Rapid assay for microbially reducible ferric iron in aquatic sediments. Appl Environ Microbiol 53:1536-1540

Kund-Hansen LC, Valeur J, Pejrup M, Jensen A (1997) Sediment fluxes, re-suspension and accumulation rates at two wind-exposed coastal sites and in a sheltered bay. Estuar Coast Shelf Sci 44:521-531

Macreadie PI, Anton A, Raven JA, Beaumont N and others (2019) The future of Blue Carbon science. Nat Commun 10:3998

Maher DT, Eyre BD (2010) Benthic fluxes of dissolved organic carbon in three temperate Australian estuaries: implications for global estimates of benthic DOC fluxes. J Geophys Res 115:G04039

Maher D, Eyre BD (2011) Benthic carbon metabolism in southeast Australian estuaries: habitat importance, driving forces, and application of artificial neural network models. Mar Ecol Prog Ser 439:97-115

Marbà N, Holmer M, Gacia E, Barrón C (2007) Seagrass beds and costal biogeochemistry. In: Larkum AWD, Orth RJ, Duarte CM (eds) Seagrasses: biology, ecology and conservation. Springer, Dordrecht, p 135-157

Martin S, Clavier J, Guarini JM, Chauvaud L and others (2005) Comparison of Zostera marina and maerl community metabolism. Aquat Bot 83:161-174

Mazarrasa I, Samper-Villarreal J, Serrano O, Lavery PS and others (2018) Habitat characteristics provide insights of carbon storage in seagrass meadows. Mar Pollut Bull 134:106-117

McGinnis DF, Cherednichenko S, Sommer S, Berg P and others (2011) Simple, robust eddy correlation amplifier for aquatic dissolved oxygen and sulfide flux measurements. Limnol Oceanogr Methods 9:340-347

McGinnis DF, Sommer S, Lorke A, Glud RN, Linke P (2014) Quantifying tidally driven benthic oxygen exchange across permeable sediments: an aquatic eddy correlation study. J Geophys Res Oceans 119:6918-6932

Middelburg JJ, Duarte CM, Gattuso JP (2005) Respiration in coastal benthic communities. In: del Giorgio PA, Williams PJ (eds) Respiration in aquatic ecosystems. Oxford University Press, Oxford, p 206-224

Editorial responsibility: Adriana Vergés,

Sydney, New South Wales, Australia

Reviewed by: F. Roth and 2 anonymous referees
Niemistö J, Lund-Hansen LC (2019) Instantaneous effects of sediment resuspension on inorganic and organic benthic nutrient fluxes at a shallow water coastal site in the Gulf of Finland, Baltic Sea. Estuaries Coasts 42:2054-2071

Niemistö J, Kononets M, Ekeroth N, Tallberg P, Tengberg A, Hall POJ (2018) Benthic fluxes of oxygen and inorganic nutrients in the archipelago of Gulf of Finland, Baltic Sea - effects of sediment resuspension measured in situ. J Sea Res 135:95-106

* Olivé I, Silva J, Costa MM, Santos R (2016) Estimating seagrass community metabolism using benthic chambers: the effect of incubation time. Estuaries Coasts 39: 138-144

*Paladini de Mendoza F, Fontolan G, Mancini E, Scanu E, Scanu S, Bonamano S, Marcelli M (2018) Sediment dynamics and resuspension processes in a shallow-water Posidonia oceanica meadow. Mar Geol 404:174-186

Kasmussen H, Jørgensen BB (1992) Microelectrode studies of seasonal oxygen uptake in a coastal sediment: role of molecular diffusion. Mar Ecol Prog Ser 81:289-303

* Reimers CE, Özkan-Haller HT, Berg P, Devol A, McCannGrosvenor K, Sanders RD (2012) Benthic oxygen consumption rates during hypoxic conditions on the Oregon continental shelf: evaluation of the eddy correlation method. J Geophys Res Oceans 117:C02021

* Reimers CE, Özkan-Haller HT, Sanders RD, McCannGrosvenor K, Chace PJ, Crowe SA (2016) The dynamics of benthic respiration at a mid-shelf station off Oregon. Aquat Geochem 22:505-527

* Revsbech NP (1989) An oxygen microsensor with a guard cathode. Limnol Oceanogr 34:474-478

* Rheuban JE, Berg P (2013) The effects of spatial and temporal variability at the sediment surface on aquatic eddy correlation flux measurements. Limnol Oceanogr Methods 11:351-359

Rheuban JE, Berg P, McGlathery KJ (2014) Multiple timescale processes drive ecosystem metabolism in eelgrass (Zostera marina) meadows. Mar Ecol Prog Ser 507:1-13

* Ståhlberg C, Bastviken D, Svensson BH, Rahm L (2006) Mineralisation of organic matter in coastal sediments at different frequency and duration of resuspension. Estuar Coast Shelf Sci 70:317-325

* Thamdrup B, Fossing H, Jørgensen BB (1994) Manganese, iron, and sulfur cycling in a coastal marine sediment, Aarhus Bay, Denmark. Geochim Cosmochim Acta 58: 5115-5129

* Therkildsen MS, Lomstein BA (1993) Seasonal variation in net benthic $\mathrm{C}$-mineralization in a shallow estuary. FEMS Microbiol Ecol 12:131-142

*Webb AP, Eyre BD (2004a) Effect of natural populations of burrowing thalassinidean shrimp on sediment irrigation, benthic metabolism, nutrient fluxes and denitrification. Mar Ecol Prog Ser 268:205-220

Webb AP, Eyre BD (2004b) The effects of two benthic chamber stirring systems on the diffusive boundary layer, oxygen flux, and passive flow through model macrofauna burrows. Estuaries 27:352-361

*Webb AP, Eyre BD (2004c) The effect of natural populations of the burrowing and grazing soldier crab (Mictyris longicarpus) on sediment irrigation, benthic metabolism and nitrogen fluxes. J Exp Mar Biol Ecol 309:1-19

Wiberg PL, Sherwood CR (2008) Calculating wave-generated bottom orbital velocities from surface-wave parameters. Comput Geosci 34:1243-1262

Submitted: May 12, 2020

Accepted: December 14, 2020

Proofs received from author(s): February 25, 2021 